\title{
WERE THE OASIS-CITIES OF THE SOUTHERN BRANCH OF THE SILK ROAD IN TARIM BASIN, CHINA, DISPERSED URBAN COMPLEXES?
}

\author{
CZY MIASTA POŁUDNIOWEJ ODNOGI SZLAKU JEDWABNEGO \\ W KOTLINIE TARIM W CHINACH BYŁY ROZPROSZONYMI \\ ZESPOŁAMI MIEJSKIMI?
}

\author{
Kasper Hanus \\ https://orcid.org/0000-0003-1550-6939 \\ Stowarzyszenie Rekonstrukcji Historycznych „GOLĘSZYCE” \\ Cieszyn, Poland \\ kasper.hanus@gmail.com
}

\begin{abstract}
This article reinterprets the urban pattern of the oases of southern Tarim Basin, which flourished in the first half of the first millennium C.E. using the dispersed urban complexes framework. Disperse urban centre, also known as a low-density urban complex, is a site that had an urban function, but its morphology was much different from compact cities of, for example, China or mediaeval Europe. Low-density urban complexes, like Tikal in Mesoamerica or Angkor in South-East Asia, despite their distinct urban functions, had the cityscape consisting of intermingled monumental agriculture, water management features and agricultural field. Thus, the oasis-cities of southern Tarim Basin were different from compact urban centres of neighbouring China and western Central Asia and showed some similarities to complexes like Tikal and Angkor. This article evaluates if those sites can be associated with low-density urbanism. Three selected sites, 尼雅 [Niya], 米兰 [Miran] and 樓蘭 [Loulan], have been evaluated for the presence of characteristic associated with low-density urbanism: dispersed monumental architecture, large scale anthropogenic landscapes modifications, and pattern of alternating housing clusters and agricultural fields. This can affect our understating of both the understanding of urbanism in the region and low-density urbanism on the global scale.
\end{abstract}

KEY WORDS: Silk Roads; low-density urbanism; agro-urban landscape; Xinjiang 


\section{INTRODUCTION}

A 5th c. Chinese traveller 法顯 [Făxiăn] described a landscape of Silk Roads' oases-cities of the Tarim Basin as follow: "throughout the country, the houses of the people stand apart like separate stars" (Legge, 1991, ch. 3, p. 1), which led many researchers to question their urban character (Padwa, 2007). Nevertheless, from a functional point of view, those oases were foci of political, religious and economic activities - which in Europe, China, South-West Asia and the Mediterranean Basin were associated with so-called "urban life". This potential dichotomy in social functions and material characteristics might be addressed by evaluating archaeological and historical sources through a low-density urbanism framework. This will allow a better understanding of the function and role of those oases and specific features within them (e.g., clusters of architecture). This article may impact an overall discussion on the global scope of low-density urbanism, yet the author will restrain from "labelling" discussed oases as certain categories of urbanism. The narrative of the article will follow three sites, 尼雅 [Niya], 米兰 [Miran] or 樓蘭 [Loulan], which were selected due to favourable preservation conditions (fig. $1 \mathrm{a}$ and b).

Researchers have increasingly devoted their attention to early cities and processes of historical urbanisation. This interest is reflected in a growing number of publications on the topic in the last two decades, such as the volume edited by Monica Smith (2003), Joyce Marcus and Jeremy Sabloff (2008), Fernández-Götz and Krausse (2016). An attempt at defining a city archaeologically, especially concerning non-European cultures, has outgrown the framework set by the attributes listed by V. Gordon Childe (1950; Smith, 2009). Most contemporary definitions of the phenomenon of the city (discussed in detail in section 2) base on its demographic or functional features (e.g., Joyce, 1983, Smith, 2016). This article aims not to evaluate early urban forms in the Tarim Basin by "ticking off" points from the list of city features based on a Eurocentric interpretation of the phenomenon of the city. Instead, the author investigates the material and social aspects of the city (actually the urban form that in European cultures is called a "city") with consideration of local urbanisation processes, which could have had a different effect on urban life than seen in Europe, the Mediterranean Basin, China and South-West Asia.

\section{LOW-DENSITY URBANISM}

Cities in Europe, the Mediterranean Basin, South-West Asia and China are understood as vastly populated areas separated from the hinterland by a clearly defined border, a physical as well as a formal one (Trigger, 2003; Cowgill, 2004; Renfrew, 2008). The physical borders are usually city walls (fig. 2), a segment of the built environment marking the border between the intramural and extramural area. Also, the symbolism of a city border is deeply rooted in some cultures of Europe and Asia, for 

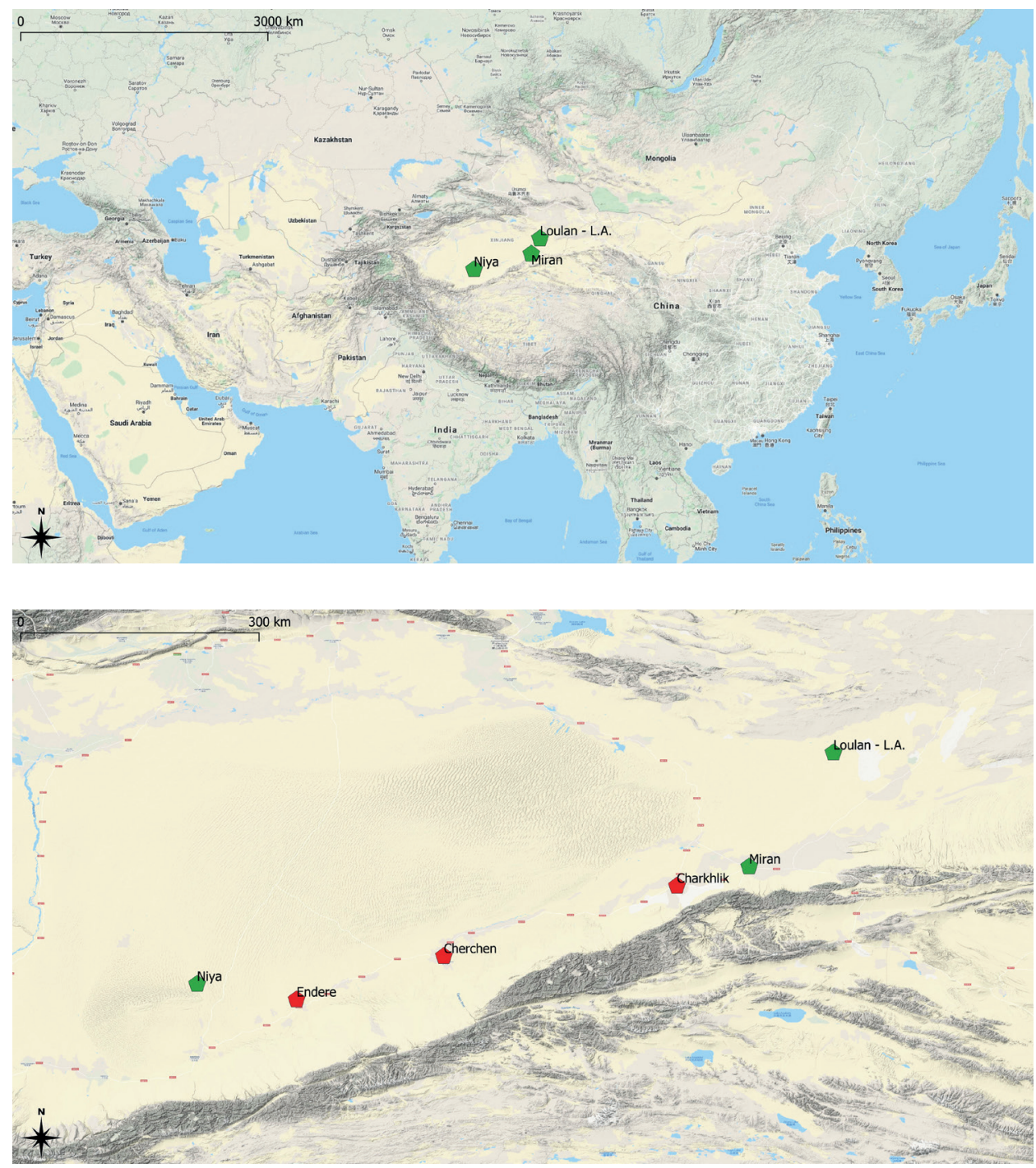

Fig. $1 \mathrm{a}$ and b. Location of sites mentioned in the article (green) and other prominent archaeological sites in the region (eds) (image by the author, data source: Google Maps)

example, the Roman symbolic border of a city called pomerium or the unique legal status of European cities during the High and Late Middle Ages (c. 1000 to 1500 C.E.). Therefore, the paradigm assumed a definition of the city which exhibits such Eurocentric features. In the 1960s, however, it was noticed that such morphology of city structure is not universal. Gordon Willey (1962) first recognised the dispersed occupational pattern, who noticed that the cityscape is not dense and the structures are separated in the archaeological landscape of the Maya lowlands. Willey, however, 
was content with calling the classical Maya culture (c. 2 nd to $8^{\text {th }}$ century C.E.) a civilisation without cities, repeating the term first used in the 1930s for ancient Egypt. A review of this opinion took place in the 1980s, when Marcus (1983), in opposition to the city's definition based on its demography and sheer size, proposed a definition based on the city's function in the landscape. Despite the dispersed character of their built environment, Maya cities were administrative and religious centres with monumental temples serving as the setting for theatrical state ceremonies. At the turn of the $20^{\text {th }}$ and $21^{\text {st }}$ century, Fletcher's $(2007,2009,2012)$ concept of low-density urbanism was further developed. The studies were based on analysis of the site of Angkor in Cambodia (fig. 3), as well as other cities located in the tropics, the Maya lowlands and Sri Lanka (Lucero et al., 2015).

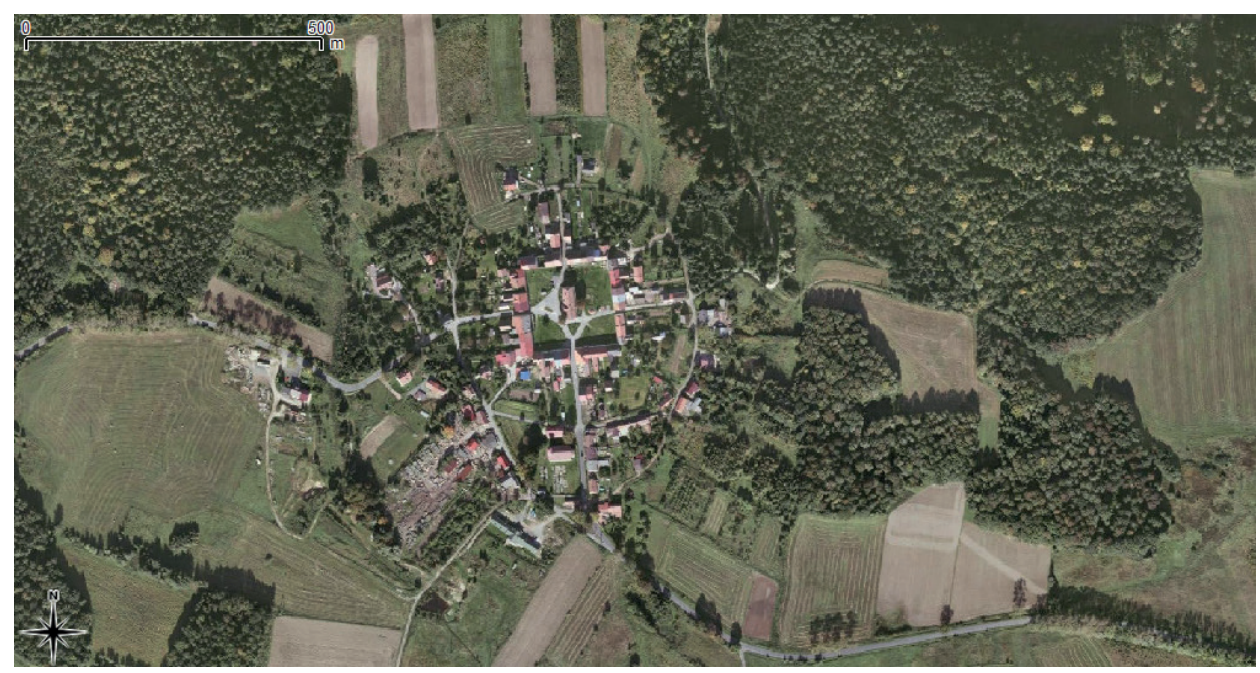

Fig. 2. A contemporary village of Złotniki Lubańskie (ger. Goldentraum, Lower Silesia, Poland) which spatial layout follows the renaissance plan of a mining town that shrank once ore depleted. The division between urban space and fields/forest is well visible (image by the author, data source: geoportal.gov.pl)

A significant revision to the low-density agrarian-based model was proposed by Elizabeth Graham and Christian Isendahl (2018). According to those authors, descriptors "low-density", "agrarian-based", and "urbanism" are misleading and instead, the term "agro-urban landscape" is proposed. It is argued that "density" is an inexact indicator as it can be understood and measured in several ways; as a number of individuals living in a given area, an amount of human activity carried out within set boundaries or as a nature of the use of space. This problem is illustrated by an example of modern city centres dedicated to commercial and production activity. Therefore occupational and human-activities densities are very divergent, and the density as a single quantitative factor should be avoided. The term "agrarian-based" 
is likewise inaccurate. Every human community depends on food, which implies that even "high-density" cities have been agrarian-based. The difference between the Classic Maya city of Tikal and modern London is that the former's food supply was grown locally (thus Fletcher called it "agrarian-based") while the latter drains its food resources from the hinterland. Therefore a food flow patterns should serve as a distinguishing characteristic. Finally, Graham and Isendahl (2018) presented a twofold argument against the term "urbanism". First, this term refers to a process determining the relationship between different entities within the settlement patterns hierarchy, for example, cities - towns - villages - hamlets. Therefore "urbanism" should be applied to studies oriented on human occupation beyond the cities themselves. The second part of the argument is that even if the term "urbanism" is replaced by "city", it would be prone to cognitive biases. It might lead to an assumption that a "normal" city is a compact one, while the low-density city is some unique case. Graham and Isendahl's "agro-urban landscape" term better reflects the phenomenon observed by Fletcher, as it deconstructs some of the potentially misleading conceptualisations discussed above.

Reinterpretation of the low-density model, recently proposed by Garrison et al. (2019), is based on a deconstruction of an urban-rural dichotomy. Based on the airborne laser scanning data (Canuto et al., 2018), Garrison et al. conceptualised the settlement pattern of the Preclassic and Classic Maya as "articulated socio-political landscape" (Garrison et al., 2019, p. 143), where both urban and rural features are interlinked. This conurban landscape consisted of areas of different density, including monumental structures of political and religious significance, farmers homesteads, fields, orchards, water infrastructure and defensive structures.

Tom Moore (2017) applied elements of Fletcher's $(2007,2009)$ low-density agrarian-based urbanism model as a framework for studies on Celtic oppida in Western Europe and proved the model's utility in better understanding urban complexes beyond the Tropics. Moore's assessment is a combination of both formal (site, occupational density) and functional (social and economic roles) characteristics of the low-density urban sites. In contrast to more conventional views that the enwalled areas solely constituted the proto-city, Moore (2017) claimed that this was just a monumental epicentre of larger continuous low-density settlement.

Based on Fletcher's original model $(2007,2009)$ and its reinterpretation and reevaluation (Isendahl, 2012; Isendahl, Smith, 2012; Graham, Isendahl, 2018, Garrison et al., 2019), three features of low-density urbanism visible in the archaeological landscape were distinguished. Although those features are used to guide an interpretation of archaeological and historical sources, their role is to facilitate the organisation and interpretation of data rather than make a formal classification of urbanism in the Tarim Basin.

The first of those features is the presence of a cluster of monumental architecture. Assuming a functional approach to the city's definition, urban complexes - unlike the hinterland - performed political, economic and administrative functions. They 
required, therefore, a built environment (Isendahl, Smith, 2012), which often carried a symbolic meaning. As an example, Smith (2016) compares the pyramid temples of the Mesoamerica to theatre scenes in which ceremonies were performed to legitimise the authorities' power. Therefore the monumental architecture is not an indicator of urban landscape per se but a material remnant of relevant past social phenomena.

For the sake of research presented in this article, the author adopted a definition proposed by Bruce Trigger (1990) who argued that monumental buildings' "scale and elaboration exceed the requirements of any practical functions that a building is intended to perform". The monumental structures, including temples, palaces, auditoriums or elite burials, were locales for economic, political and social interactions - often associated with the urban life (Trigger, 1990; Revell, 1999; Isendahl, Smith, 2012).

The second feature is the presence of large scale landscape modifications and massive infrastructural projects. Fletcher $(2009,2013$; Fletcher et al., 2008) noted that all low-density urban complexes he studied had a sophisticated water control system designed to increase agricultural production. It is explained that all case studies discussed by Fletcher (2013; Lucero et al., 2015) are located in polarised climate zones with long dry season interrupted by periods of heavy rainfall. Therefore to reduce water availability disparity between dry and wet seasons and increase food production, complex irrigation systems were introduced. For example, at Greater Angkor, the continuous network of reservoirs and canals covered over $1000 \mathrm{~km}^{2}$ (Miksic, 2000; Fletcher et al., 2008; Evans et al., 2007). Other agricultural-oriented landscape modifications present at the sites located with complex topography, such as Tikal, Guatemala, were terracing (Fletcher, 2012; Canuto et al., 2018). The slopes were levelled to create a series of terraces suitable for cultivation to increase an acreage of agricultural land otherwise limited by a hilly landscape.

The third feature of the definition proposed by Fletcher (2009, 2012, Lucero et al., 2015 ) is a presence of open, often agricultural, land "interwoven" with the monumental architecture, massive infrastructure and dispersed residential buildings. The recent surveys using airborne laser scanning (Evans et al., 2013; Evans, 2016, Canuto et al., 2018) allowed the low-density model to be further refined as it showed that mapped low-density complexes of Angkor, Cambodia and Tikal, Guatemala, were formed by polynuclear urban landscapes. Beyond the core formed by a cluster of monumental structures and higher occupational density, the vast peripheries of secondary highly urbanised clusters, dispersed residential buildings, agricultural and open areas existed. The whole system was spanned by water infrastructure and road network (Evans et al., 2013; Lucero et al., 2015; Garrison et al., 2019).

Fletcher (2009; Graham, Isendahl, 2018) saw the low-density, agrarian-based urbanism as "a category" of the possible urban configurations. Three archaeological sites, known today as 尼雅 [Niya], 米兰 [Miran] and 樓蘭 [Loulan], will be studied to re-evaluate the urban centres in southern Tarim Basin, using framework based on low-density theory. These sites are located on the southern branch of the Silk Road, in the autonomous region of Xinjiang-Uighur, in the People's Republic of China. The sites were chosen because of abundant archaeological and historical sources available, 
including data from excavations (Stein, 1907, 1921; Jing, 1999; Rhie, 1999; Luo et al., 2017; Hanus, 2020) and promising results of a remote sensing survey conducted by the author for the study presented in this article.

\section{THE OASES OF SOUTHERN TARIM BASIN}

The selected sites are located in the south-eastern corner of the Tarim Basin, on the northern slopes of the Altyn-Tagh mountains reaching over 5,000 metres above sea level. These mountains remain of great importance to modern populations since the glaciers feeding the rivers flowing through the Tarim Basin (Padwa, 2007).

Since it is one of the driest places on earth, life would not be possible without access to these mountain springs. In the fertile ring between the mountains and the Taklamakan desert, numerous oases allowing human settlement appeared. Based on their location, these oases can be divided into "piedmont oases", which occupied the transition zones between the land covered with pebbles and the sands of the deserts, and "terminal oases", that appeared in interdunal valleys and alluvial fans (Padwa, 2007). Environmental changes in this area were very dynamic, and the oasis-settlements that existed in this area had to overcome several threats to long-term survival, such as aridity, drifting sands, shifting rivers and eventually periodic flooding caused by the surplus of water created during the spring thawing of snow in the mountains (Padwa, 2007). Our knowledge of the development of these kingdoms comes from two sources: archaeological data and historical records. The former mostly derive from the exhaustive work of British-Hungarian explorer Sir Mark Aurel Stein $(1907,1921)$, who surveyed the area at the beginning of the $20^{\text {th }}$ century, as well as the new information acquired by contemporary Chinese and international archaeological research projects (Chen, 1984; SJJRNS, 1999; Luo et al., 2017). Historical documents mainly consist of both local texts written in the Kharoșthī script in the Gāndhārī language, as well as the rich Chinese annals, such as 太史公書 [Tàishĭgōng shū / Records of the Grand Historian] or 前汉书 [Hàn shū / Book of the former Han].

Mainly, the history of the area can be divided into three periods (di Cosmo, 2000): the first period lasted until 77 B.C.E., defined by the existence of the independent polity of Krorayina, known in Chinese sources as 楼兰 [Loulan]. Due to limited archaeological evidence and lack of historical sources, it is impossible to determine when the local agro-pastoral populations formed early kingdoms (a kingdom is defined in this context as a complex society with centralised political power). In most well-preserved corpses and grave goods, the archaeological finds that the native population consisted of agro-pastorals of Western origins (Ma, Wang, 1994). The language spoken by those communities was most likely a dialect of Tocharian, now extinct branch of the Indo-European language family (Mallory, 2010). It is difficult to estimate the exact area under the control of the rulers of this kingdom due to a lack of local and a scarcity of Chinese written sources. However, it is known that its strategic location on a trade route made Krorayina an area of military and political competition between Han China and 
nomadic 刚奴 [Xiongnu]. The second period began when a drastic change took place in 77 B.C.E. In that year, a Chinese envoy 傅介子 [Fu Jiezi] killed king 安歸 [Angui], accused of supporting 匈奴 [Xiongn]). The Han placed his brother 尉屠老 [Weituqi] on the throne, creating a puppet-state renamed by the Chinese as 鄯善 [Shan-Shan]. It is worth stressing that the appearance of military colonies related to the direct control by the Han forces brought a significant change in settlement patterns.

The third period began in the $3^{\text {rd }}$ century when the first inscriptions in the Kharoșthī script were written (Rhie, 1999). This period is connected to an introduction of Buddhism in the region and interweaving periods of sovereignty and subordination to various Chinese factions. During that period, the irrigated area reached its maximum extent. However, the lack of proper chemical or physical dating of structures discussed below makes it impossible to build an absolute chronology (Bertnard, 2012; Li et al., 2017). On the other hand, the relatively short time span of oases communities existence (restricted by gradual abandonment after the $4^{\text {th }}$ century, most likely due to deteriorating environmental conditions) allowed a simplification assuming that structures were concurrent. Nevertheless, further research on dating will open new lines of academic query, for example, related to the formation and development of settlement patterns.

\section{THE LOW-DENSITY URBAN COMPLEXES OF 鄯善 [SHAN-SHAN]}

The potential inconsistency between the settlement patterns of oases of 邺善 [Shan-Shan] and "traditional" definition of a city has been noticed by researchers discussing sites in 樓蘭 [Loulan] area. 樓蘭 [Loulan] is not a single site but a complex of multitemporal sites located on banks of the Lop Nor lake (Stein, 1907, 1921; Rhie, 1999). Stein designated each specific site within the complex with an alphabet letter: L.A., L.B... to L.Q. Some researchers refer to three of those sites, L.A., L.E. and L.K., as "walled cities" (discussion in Rhie, 1999). Within those enclosures, numerous religious and administrative buildings - which role is testified by finds of documents of official nature - were discovered. In addition, historical texts suggest that the enclosures held royal residences and garrisons. However, the relatively small area of enclosed space (e.g,. L.E. is $450 \times 400 \mathrm{ft}$., approximately $140 \times 120 \mathrm{~m}$, Rhie, 1999) makes it difficult to interpret those places as compact cities - especially as a historical document, a Chinese military intelligence assessment, states that 樓蘭 [Loulan] was inhabited by 14100 people (di Cosmo, 2000).

The author has evaluated the archaeological and historical sources for each of the oases separately, following the conceptual framework for studying low-density urban complexes. However, the state of preservation between the sites differs. Therefore some aspects might be less visible in the records or impossible to verify.

As mentioned above, the site of 樓蘭 [Loulan] is, in fact, a network of more or less integrated clusters of architecture. Three regional groups could be identified: northern group, consisting of L.E. and L.F., a central group, formed by L.A., L.B., L.C., and L.D., and southern group, constituted by L.K., L.M., and L.L. (fig. 4). Each of the 


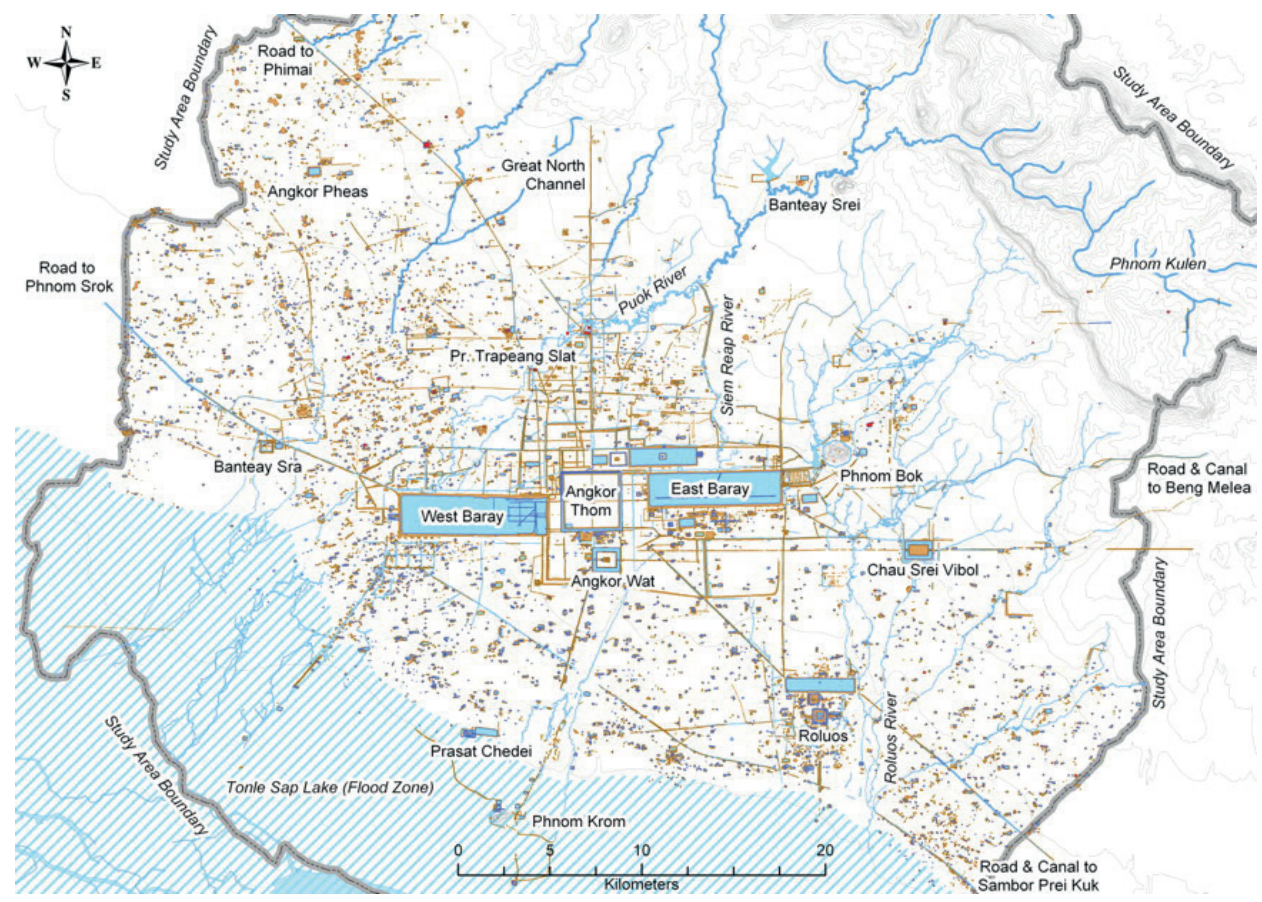

Fig. 3. Greater Angkor (Cambodia) as an example of an agrarian-based, low-density urban complex. Brown outline represents residential areas and roads while blue - water management infrastructure. (Image source: Evans et al. 2007).

groups focuses around an enwalled monumental compound, respectively L.E., L.A., and L.K. Previous studies conceptualising those compounds as qalas, forts inhabited by the aristocracy, known from western Central Asia (e.g., Merv Oasis in Turkmenistan; Lamberg-Karlovsky, 1994; di Cosmo, 2000) and the author's interpretation of archaeological data points out to a conclusion that those places were not "stand-alone" cities, but what Fletcher called the core of monumental architecture. The site of L.A. is an enclosed area of approximately 420 by 300 meters, with a single gate on the western side (fig. 5). Within the walls, a monumental stūpa and at least five buildings, which function the author has identified as administrative, were located. The most prominent structure was designated by Stein (1921) as L.A.II-L.A.III and nicknamed "Ya-men", after Chinese world 衙門 [yámén] meaning a residence in which the Chinese Imperial mandarins worked and lived. Indeed, the spatial characteristic of the remaining parts of the compound in 樓蘭 [Loulan] reflects features of the later Chinese administrative residence (Nimick, 2005). The surviving parts of the L.A.II/III are concentrated around a massive wall in the shape of the letter T (fig. 6). The length of the longer stretch of the wall is 45 meters, while shorter 32 meters, yet the scattered timber debris suggests that the compound was much larger before various structures surrendered to the elements (Stein, 1921, p. 376). The surviving rooms include spaces for public meetings with distinctive sitting platforms for participants (L.B.III.iii 


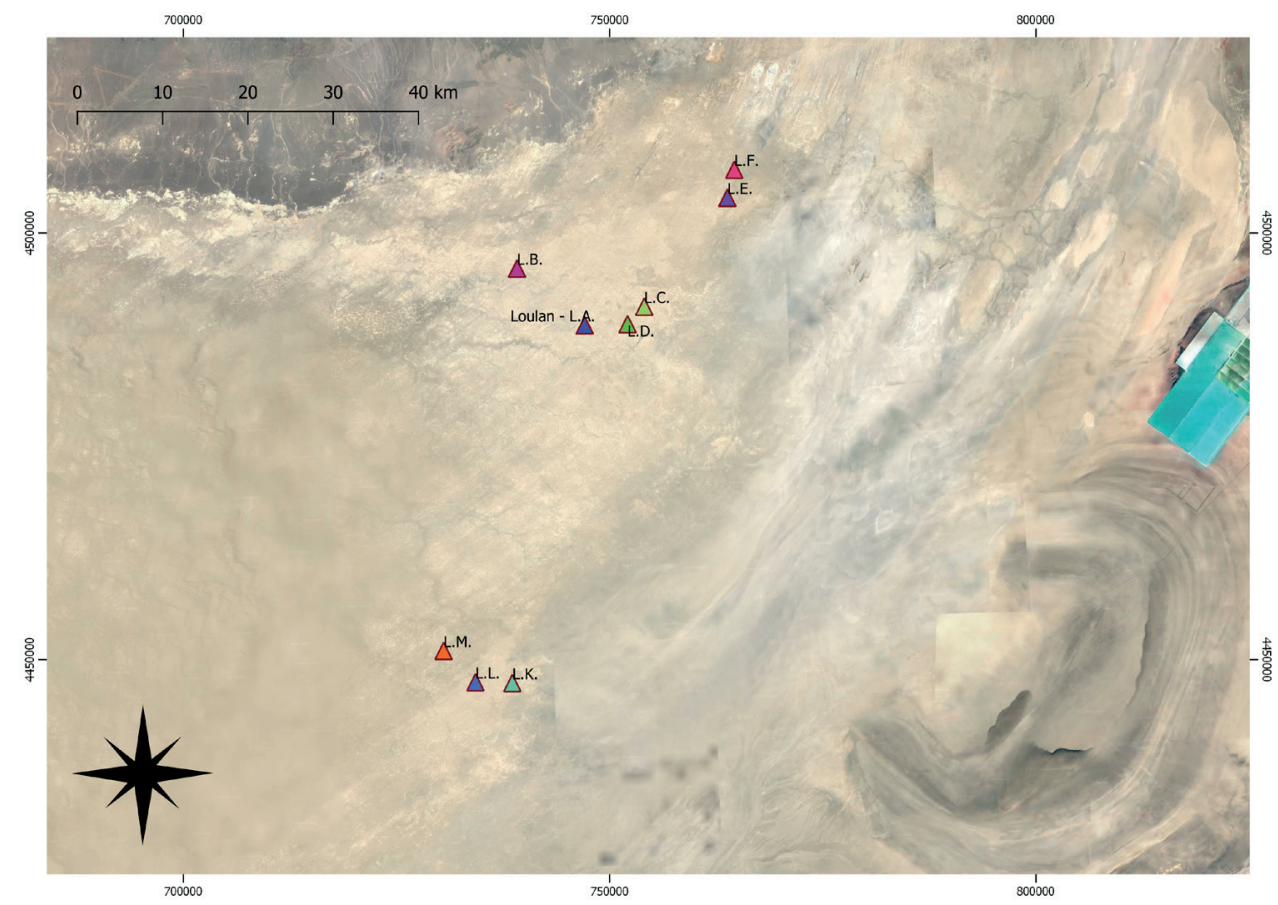

Fig. 4. A map presenting major archaeological sites in the Lop Nor area. The concentration of sites around L.E. in the North, L.A. in the centre and L.K. in the South is visible. The coordinate system of the grid is UTM zone 45. (Image by the author and Joanna Koczur, background data source: Google Earth)

and L.B.II.vi); a back office, in which an archive of administrative documents was excavated (L.A.II.v); and a row of narrow rooms (L.A.II.i to L.A.II.iii) interpreted as prison cells or storages for goods. As the public meetings or document circulation is a clear distinction of an administrative function, the prison cells or storage areas has been excepted by the author as well, as such a compound, similar to Chinese 樓蘭 [Loulan], might have juridical and/or fiscal functions. In the latter scenario, the rooms were used to store taxes paid in goods, such as grain (Atwood 1991). Besides the compound L.A.II/III, which dominated the intramural area of L.A., the further four smaller administrative residences (which linked public functions and living quarters for high ranking official) were excavated: L.A.I., L.A.IV, L.A.V. and L.A.VI (fig. 7). The buildings shared similar characteristics: a distinct layout in which official and private spaces were separated (e.g., for the compound L.A.I., rooms L.A.I.i to L.A.I.iii formed official space, while room L.A.I.iv is a remnant of a private quarter). In each of those locations, which state of preservation varies, remnants of the public meeting hall and/or vast quantities of administrative documents were discovered, which strongly implies those residences' administrative role. Therefore, the author's interpretation of archaeological evidence assumes that the enwalled area of L.A. served as a centre of political power. This role manifests by monumental religious architec- 


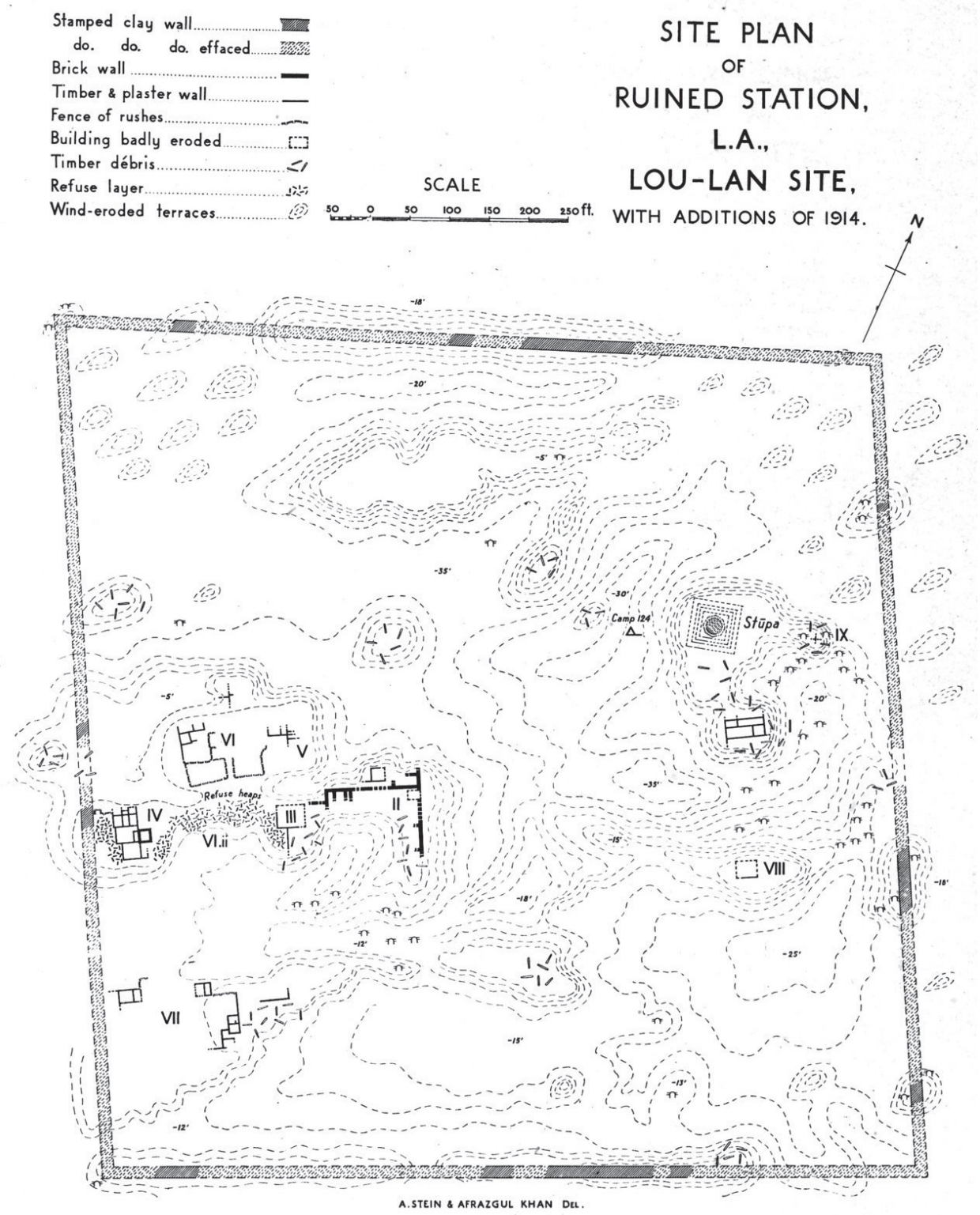

Fig. 5, A plan of L.A. enclosure prepared during Stein's fieldwork in the Loulan area. (Image source: Stein 1921) 


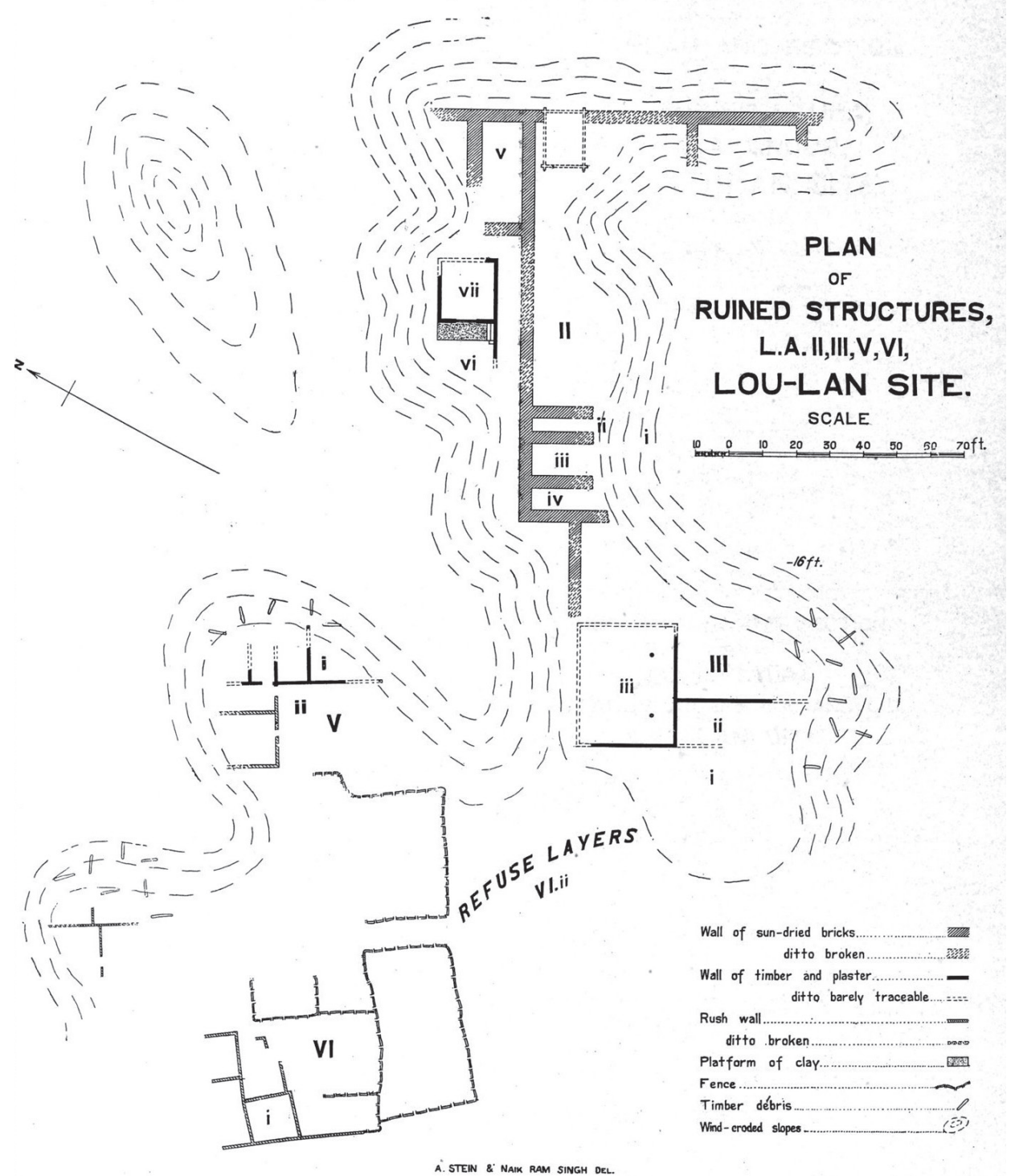

Fig. 6. A plan of Loulan's „Ya-men” published in Stein's excavations report. (Image source: Stein 1921) 
ture and secular buildings associated with political elites and bureaucratic apparatus. However, this architectural complex did not exist in a landscape vacuum but might have been surrounded by what the author claims to be a penumbra of low-density occupation. However, such a possibility is difficult to verify due to a bad state of preservation that led Stein (1921) to document only "heaps" of degraded construction timber. The biggest cluster of surviving architecture has been marked by Stein (1921) as L.B. and is located along the road leading from the L.A. west. The four subgroups of the L.B. are stretched on the distance of $13 \mathrm{~km}$, in roughly equal intervals, between the L.A. and furthers group containing structures L.B.I. to L.B.III. The subgroups share a similar layout - a stūpa in the middle (respectively L.B.II, L.B.V., L.B.VI and unmarked easternmost stūpa) and surrounding domestic buildings (L.B.I., L.B.III around L.B.II; L.B.IV around L.B.V. and unmarked remains of construction timber around two latter stūpas). Stein (1921) observed that the subgroups were surrounded by remnants of agricultural fields and document remnants of two major water canals in the vicinity of L.B.IV-V and the unmarked easternmost stūpa. On the eastern side of L.A., other sites have been located. A cemetery, marked as L.C., has been located on a small mesa. The L.D., located approximately $4 \mathrm{~km}$ north-east from the walls of L.A., consisted of a single badly eroded residential structure with at least eight rooms of varying size. Interpretation of this structure as a domestic building is based on portable artefacts excavated by Stein (1921). $3 \mathrm{~km} \mathrm{N.N.E.} \mathrm{from} \mathrm{the} \mathrm{L.A.,} \mathrm{another}$ badly eroded structure, marked as L.G., was surveyed and labelled by Stein (1921) as a dwelling. Eight hundred meters south of L.D., a section of the dry canal bed, c. 20 meters wide, c. 1.5 meters deep and flanked by rows of poplar trees. On numerous occasions in his reports $(1921,1928)$, Stein commented that the scattered remains, such as pottery débris, were abundant along the routes he used to move between his camp, L.A. and its satellite sites.

A similar spatial arrangement has been observed for settlement cluster in the northern portion of 樓蘭 [Loulan] area, centred around site L.E. - the enwalled compound, called by Stein (1928) castrum, protected by 140 by 120 -meter wall, with numerous structures inside (fig. 8). Unfortunately, the erosion prevents drawing any meaningful conclusions about the layout or function of those buildings. Approximately 4 kilometres to the northeast, a site L.F. was located on top of a mesa. The northern portion of the mesa was occupied by enwalled settlement, while a cemetery was located in the middle. The area stretching from L.E. towards L.F., and further northeast (towards Kuruk-Darya river) has been called by Stein $(1928,274)$ "belt of ancient cultivation". Stein's judgement is supported by finds of eroded dwellings (only one of them, L.I., has been plotted on his detailed map), scattered portable artefacts (mostly pottery sherds), and remnants of fields.

Interpretation of the southern cluster, centred around fortified site L.K., should take into account a possibility that those sites were Chinese military installations constructed during 前涼 [Former Liang] period, and L.K. itself was a garrison mentioned in the historical sources as 海頭 [Haitou] (Rhie, 1999). The L.K. was protected by a 190 by 100 -metres wall, with a single gate within the northern section 


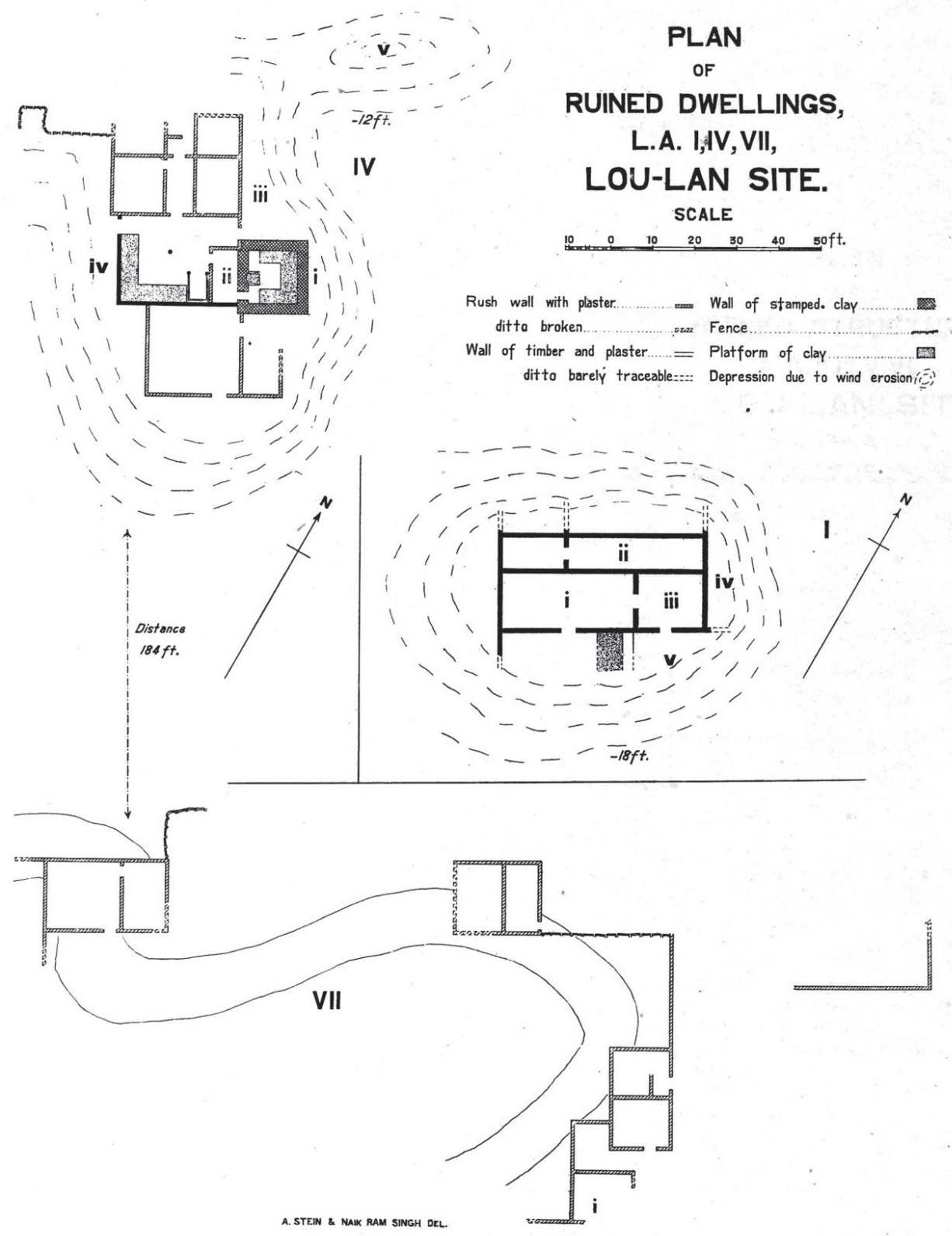

Fig. 7 Plans of smaller administrative residences located within the L.A. enclosure. (Image source: Stein 1921) 
of the wall. The structures within the enclosure have been much deteriorated due to intense Aeolian erosion, yet the artefacts recovered support the interpretation of this site as a Chinese garrison. A site L.L., located to the west from the L.K., shared layout and constriction characteristics of the latter, only being smaller in scale. Approximately 5 kilometres from L.L., a cluster of residential structures, marked as L.M., was located. In total, five compounds, L.M.I. to L.M.V., were located within a valley formed by two ephemeral creeks (Stein, 1928). The compounds, which internal layout and associated portable artefacts suggest residential character, were evenly distributed along the northwest-southeast axis, approximately 1.5 kilometres long (fig. 9). Stein $(1928,196)$ observed scattered archaeological remnants, mainly pottery and timber, in the areas between the compounds and contemplated a possibility that the documented structures were more robust residences of local elites, while the commoners dwelled in modest houses that have been less resistant to the elements. One of Stein's surveyors found another cluster of ruins, the L.R., constructed in "similar manner of those at L.M." (Stein 1928, p. 197), approximately 3 kilometres to the northwest, yet the limited time and resources prevented detailed documentation.

At the site of 米兰 [Miran], at least fifteen monumental structures of different kinds have been reported (Rhie, 1999). The most prominent one - M.I. should not be accounted for, as it is a Tibetan fort build in the second half of the first millennium after the site was mostly abandoned (fig. 10). The structure M.II was excavated twice by Stein $(1907,1921)$, who interpreted this building as a vihāra, a Buddhist monastery. The vihāra was a large platform with niches in which the remnants of clay or stucco sculptures were found. The superstructure was heavily damaged, yet Rhie (1999) hypothesises that it was a stupa, and the overall layout of the complex was similar to monastic sites from Taxila. The rest of the ruins recorded by Stein, except M.X. and M.XII (most likely watchtowers), were Buddhist stupas and shrines. Rhie (1999) points out that the religious sites are numerous and finely decorated (e.g., wall paintings from M.III and M.V., fig. 11). Therefore it is reasonable to assume that the oasis was a centre of religious life on at least a regional scale. However, the inspection of the oasis plan fails to determine a single concentration or cluster of the monumental architecture of high social significance. Contrary, the vihāra, the stupas and the shrines are evenly distributed across the agricultural landscape of the oasis.

米兰 [Miran] provides a unique opportunity to study a water management infrastructure of the region, as in contrast to 尼雅 [Niya] and 樓蘭 [Loulan] the continuous irrigation system, covering more than 20 square kilometres has been preserved on this site (Luo et al., 2017; Hanus, 2020). A detailed survey of the irrigation has been possible using satellite remote sensing. The canals are visible on the space-borne imagery as distinctive linear features dug into the ground and formed by two parallel embankments, altering local micro-topography and manifesting on the imagery as elongated shadows (fig. 12). The system has been designed to capture water from a glacier-fed river and distribute it to the fields, using a hierarchical network of canals. The top tier 


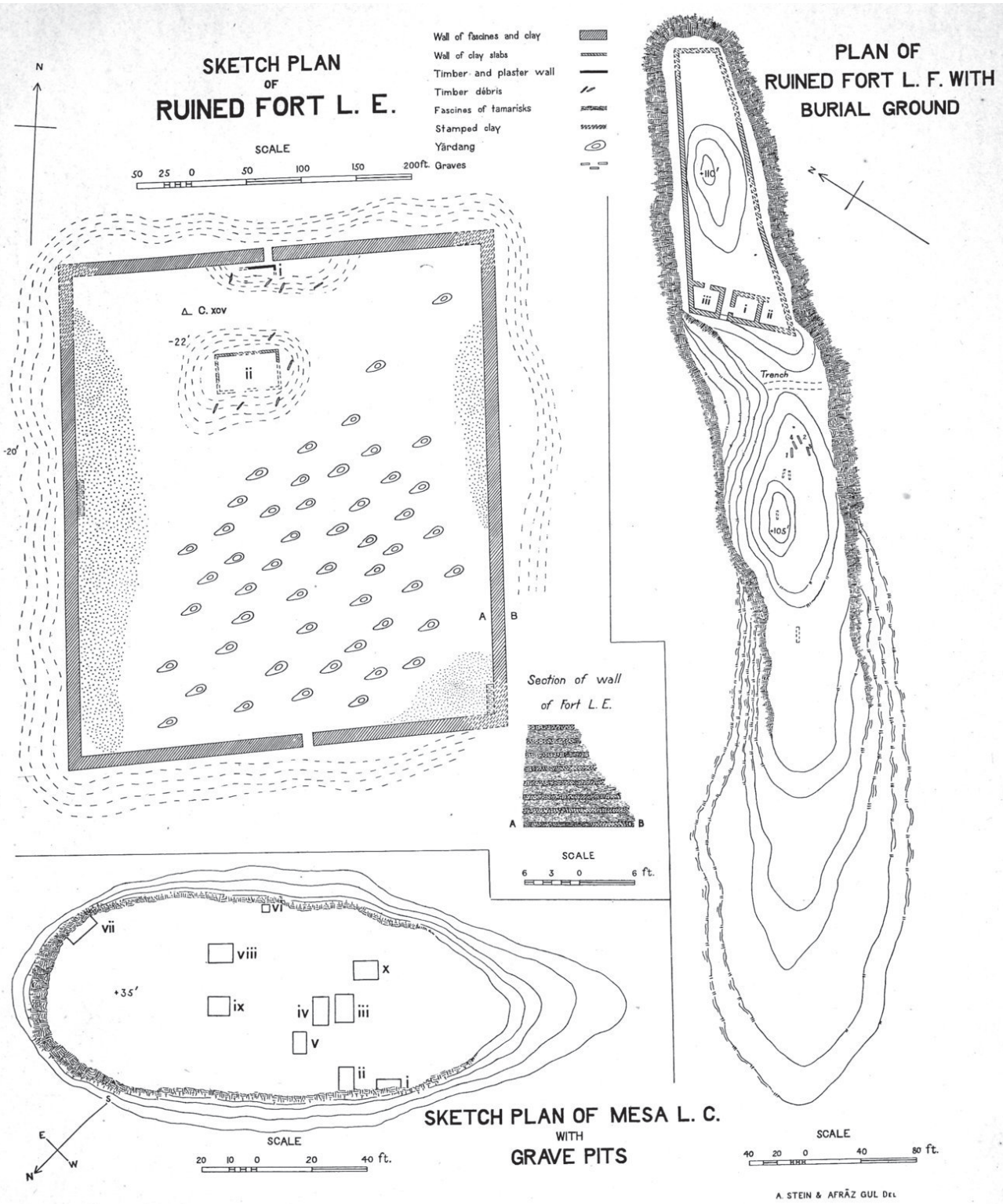

Fig. 8. Plans of two sites of the northern group, L.E. and L.F. and additional sketch of graveyard L.C. located in the central group (near L.A.). (Image source: Stein 1921) 


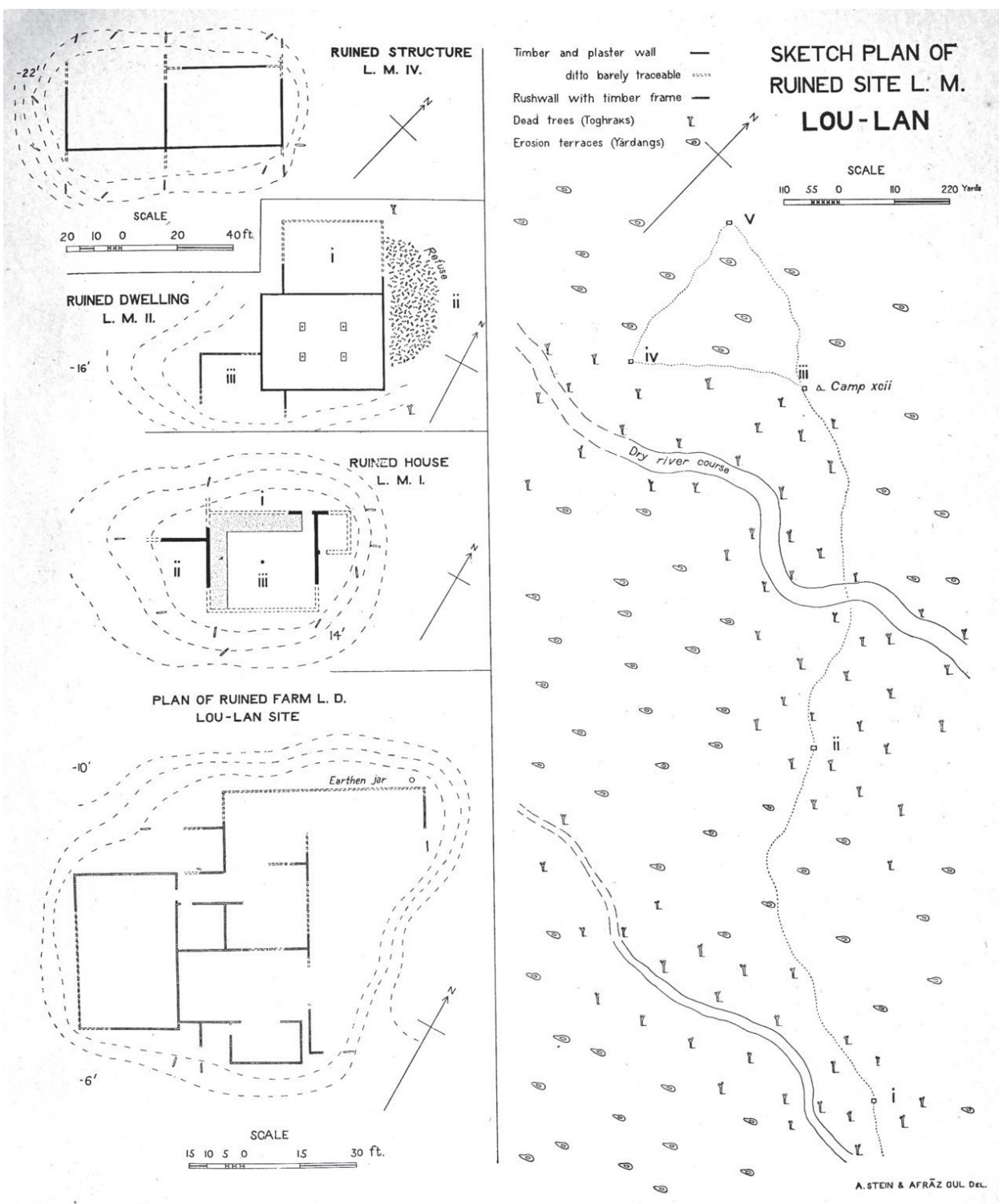

Fig. 9. A general map of site L.M. and detailed plans of architectural structures. (Image source: Stein 1928) 


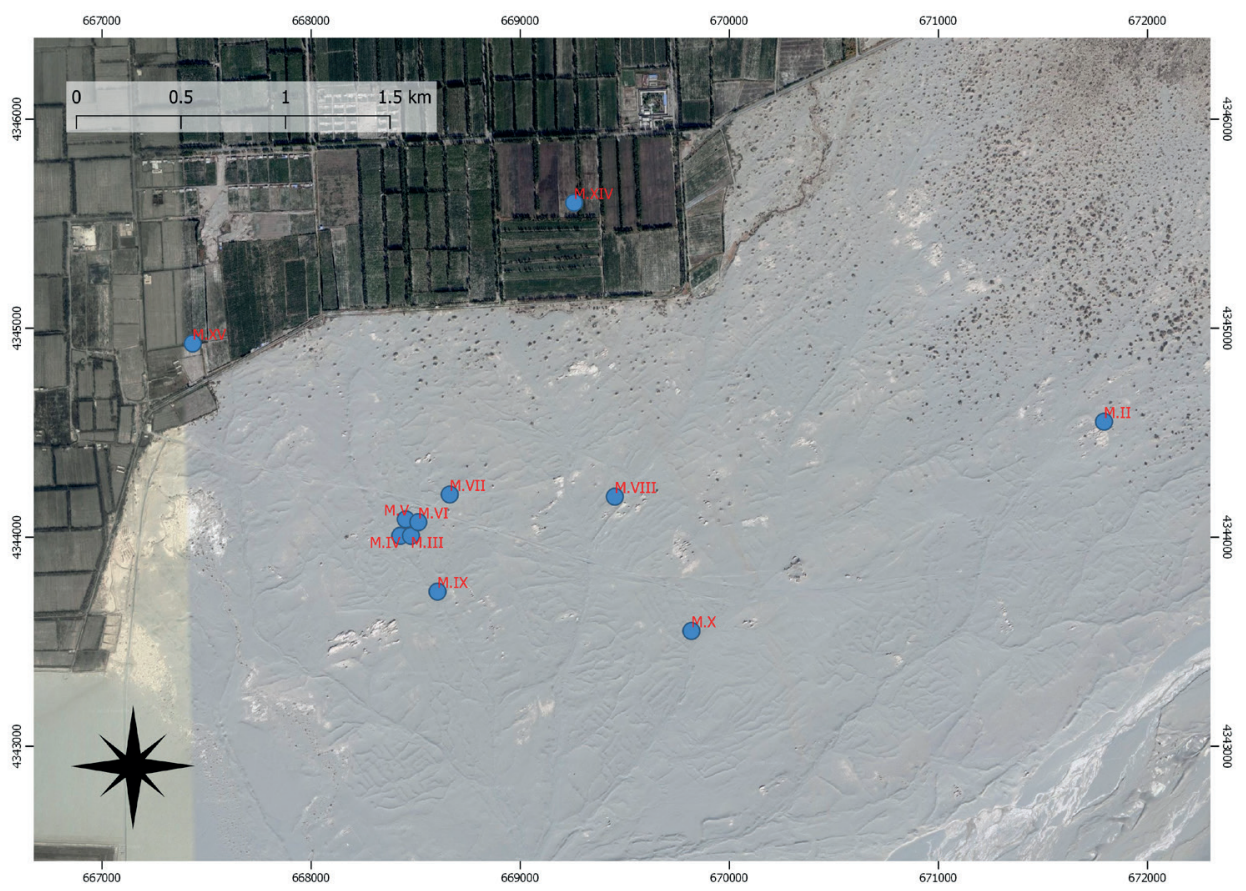

Fig. 10 A satellite image of 米兰 [Miran] with the structures discussed in the text highlighted. The coordinate system of the grid is UTM zone 45. (Image by the author and Joanna Koczur. Image source: Stein 1907)

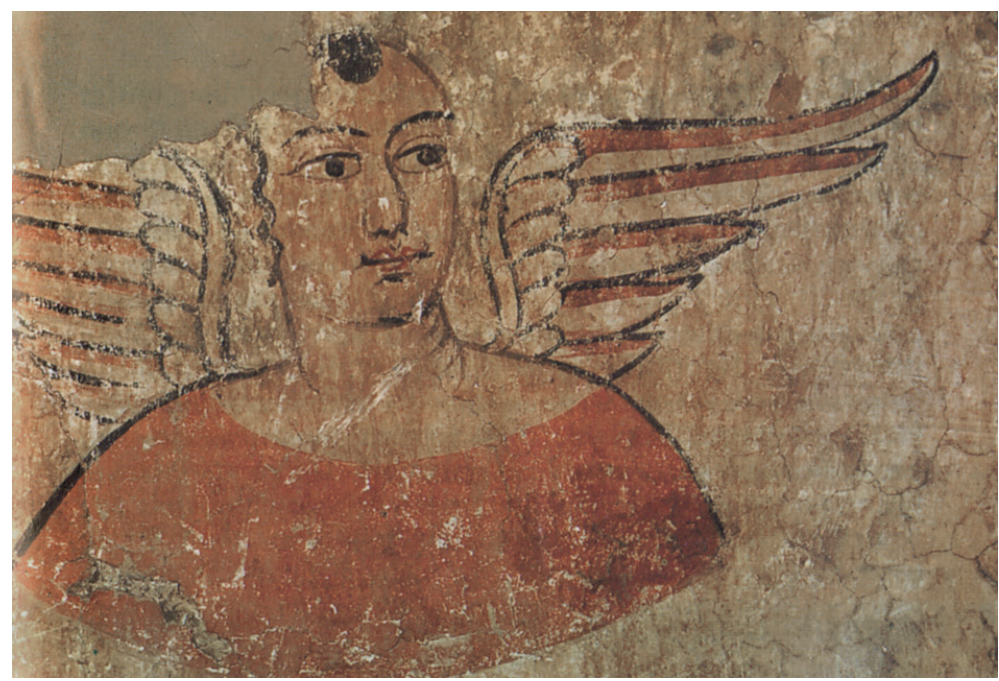

Fig. 11. Fresco from 米兰 / Miran. Rhie (1999) summarizes a discussion among art historians that indicates strong influences from Gandhāra (contemporary Pakistan) and beyond (image source: Yaldiz. M., 1987. Archäologie und Kunstgeschichte Chinesisch-Zentralasiens «Xinjiang». Leiden: Brill) 


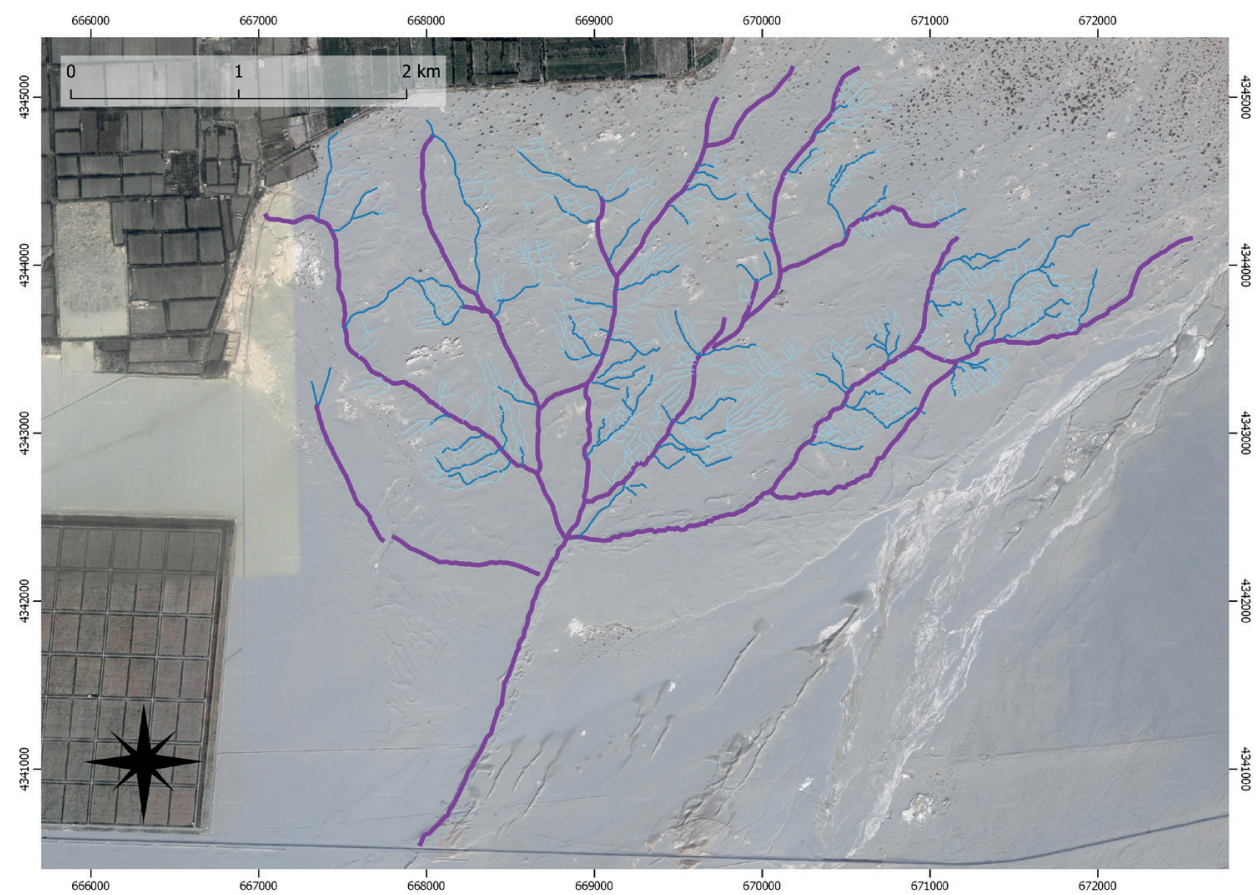

Fig. 12. Contemporary satellite imagery overlapped with an interpretation of the water management system. Purple lines represent primary canals, navy blue - secondary and light blue - tertiary. The coordinate system of the grid is UTM zone 45. (Image by the author and Joanna Koczur. Source of background image: Google Earth).

of canals consisted of the central feeding canal, which has captured water several kilometres upstream from a nearby river (it is worth noticing that the site itself is located at a safe distance from a river, which often flooded its vicinity during spring runoffs) and six main canals, distributing the water around the oasis. Secondary canals, which joined the mainlines at $90^{\circ}$ angle, facilitated the water transportation to agricultural fields distant from the main canals. Finally, the tertiary canals delivered water to individual plots of land. As the net of irrigation canals densely covers the whole site, as well as it is argued (Hanus, 2020) that without artificial water supply the food security could not be provided for the increasing population of the oasis, it is safe to assume that the whole landscape of has been米兰 [Miran] engineered (towards providing adequate water supply).

Regrettably, no remnants of residential architecture or dwellings have been found by the archaeologists at the site of 米兰 [Miran] (Stein, 1921, 1928; Chen, 1984; Luo et al., 2017). Drawing comparisons from the material remains from nearby oases of 尼雅 [Niya] and 樓蘭 [Loulan], as well as historical sources, it is very likely that some sort of permanent housing structures existed at 米兰 [Miran] and their absence in archaeological records must be attributed to the current state of research. 
The westernmost case study, the oasis of 尼雅 [Niya], lacks the enwalled administrative centres on a similar scale to L.A. or L.E., yet the analysis of the author of both internal layout and settlement patterns suggest that the public architecture has existed in this oasis (Hanus, 2020). As in the case of 樓蘭 [Loulan], Stein $(1921,1928)$ observed that common dwellings, due to inferior construction techniques and materials, deteriorated much faster than residences of the elites. Thus the latter are more visible in the archaeological record. The author argues that most of those residences served an administrative role. The accessibility analysis (Hanus, 2020) shows that while residences interpreted as private had simple accessibility arrangement, the so-called administrative residences had several areas serving distinct functions. Those spaces include gathering places for public ceremonies and meetings, back-offices for administrative proceedings and residential quarters for high-ranking executive official, his family and retinue. As the detailed investigation on each of the administrative residences is presented in Hanus, 2020, a residence marked as N.XXIV will be presented as an example of such a compound (fig. 13). The residence is divided into four areas, which were not internally connected and had independent entrances: two public spaces, a back-office and private quarters (fig. 14). The public spaces share a similar accessibility arrangement. Access to a monumental hall (respectively cells iv and vii) is controlled by at least two vestibules and/or waiting rooms (respectively ix->x and v->vi). The halls themselves had a U-shaped sitting platform for the audience, a fireplace and at least one central post supporting roof. The remnants of construction timber and other artefacts (e.g., decorative rugs) testify that those rooms were showily decorated. The document found in those locations in few instances allowed linking the administrative residence with its high-ranking tenant, for example, a royal governor or a chief tax collector (Padwa, 2007; Hanus, 2020). Those administrative residences did not form any cluster but were evenly distributed within the landscape of the oasis.

Along the course of the river, over fifty non-monumental dwellings were discovered, which are distributed over the area covering approximately $70 \mathrm{~km}^{2}$ (fig. 15). Archaeological excavations (Stein, 1907, 1921; Jing, 1999; SJJRNS, 1999; Padwa, 2007) shows that the households were often adjacent to canals, orchards and fields. Housing was likely to be primarily low-rise (one or occasionally two storeys). Excavations data is reinforced by ethnohistorical studies of helmets from Atayayleke (Fournet, 2001). The structure N.IX, which serves as an example of a "typical" household, was located just west of a canal, between which and the house an orchard was located, which identification was possible thanks to the preservation of tree trunks in the arid environment (Stein, 1907). The building consisted of at least five cells: three living and cooking quarters in the northern section and two storage rooms in the southern part (fig. 16). Another example of an agricultural establishment at the site of 尼雅 [Niya] is N.XLIV (Stein, 1928), which shows a spatial correlation between irrigation canal or natural watercourse, households, 

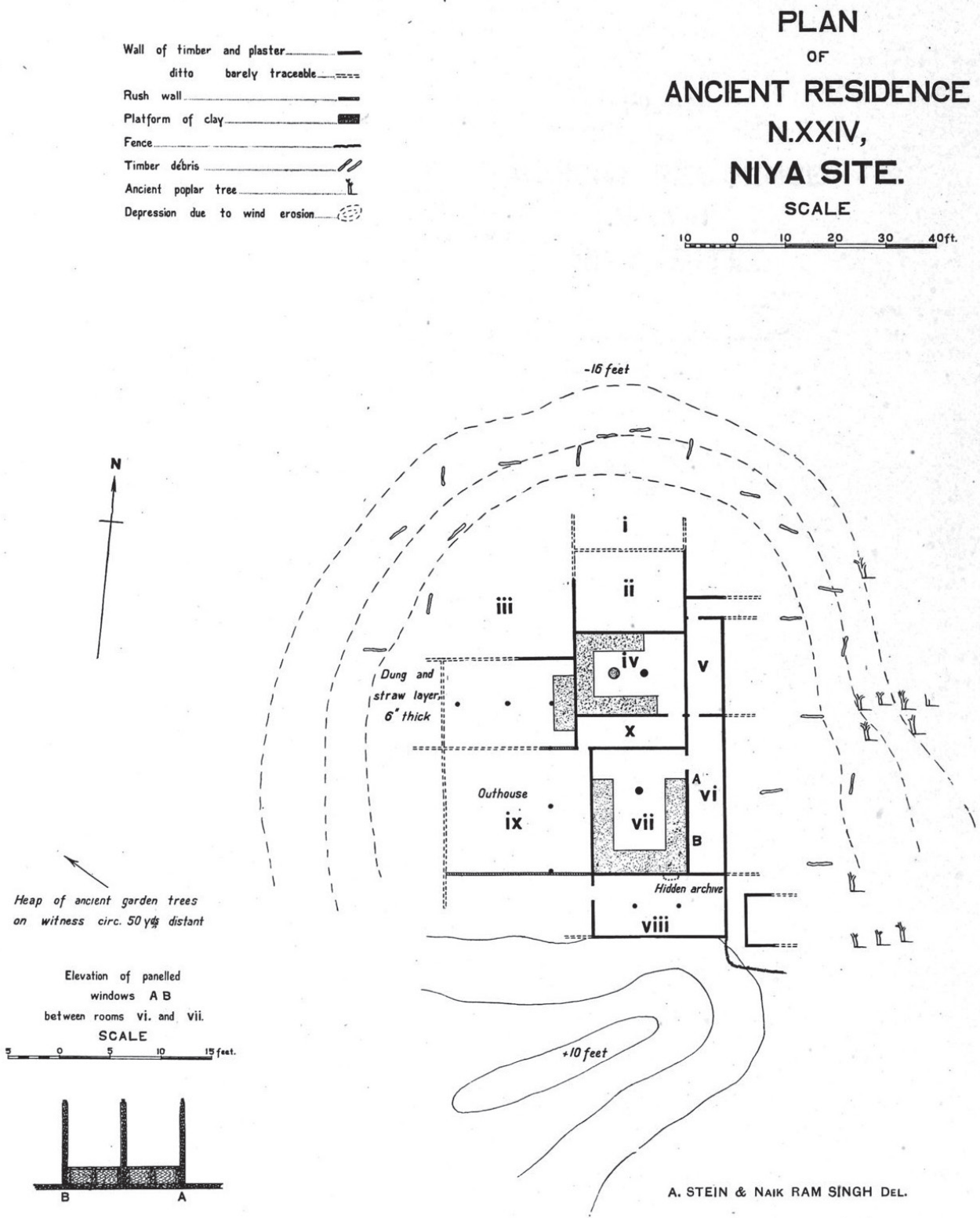

Fig. 13. A plan based on Stein's excavations of administrative residence N.XXIV. (Image source: Stein 1921) 


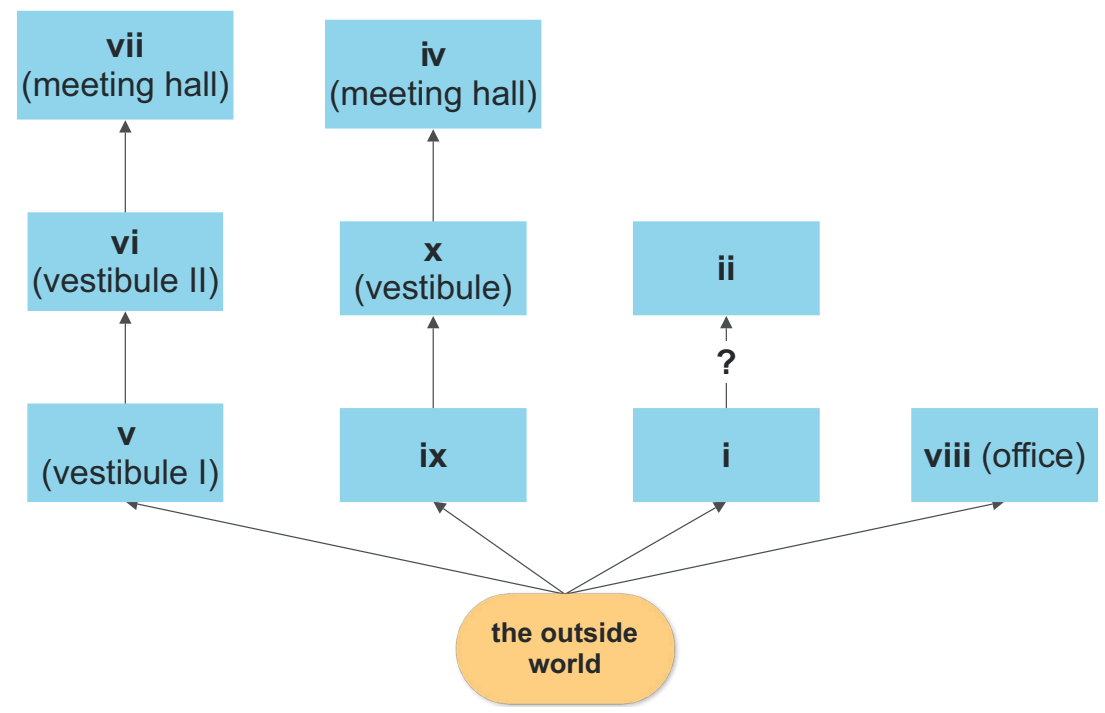

Fig. 14 An interpretation of internal spatial layout of N.XXIV. Each rectangle represents one cell (room), while arrows indicate a passage (e.g. a doorway)

orchards, vineyards and possible agricultural land (fig. 17, detailed description of private residences in Hanus, 2020). The location of identified households is significant because it proves no aggregations of occupation zones. Furthermore, the fact that the oasis was occupied for a few centuries only reduces the possibility of misinterpretation of the residential pattern due to establishing an absolute or relative chronology.

The analysis of the settlement pattern of 尼雅 [Niya], reinforced by interpretation of historical texts, done by Padwa (2007), draws a picture of an oasis in which dwellers were organised into administrative units of (around) one hundred and ten households. Each of those units was socially centred around the residence of an official who was a king's representative. Therefore those residences served as public buildings for the community, and their administrative role is confirmed by documents excavated in situ (Stein, 1907, 1921; Padwa, 2007). The Chinese sources indicate that the oasis was inhabited by 3360 people (di Cosmo, 2000).

The remnants of water management infrastructure are limited to isolated sections of irrigation canals and several water ponds (Bertrand, 2012). It might be interpreted that the same sort of continuous irrigation system existed at the site, yet in the absence of direct evidence, it is impossible to estimate its characteristics and assess the scope of landscape modifications. 


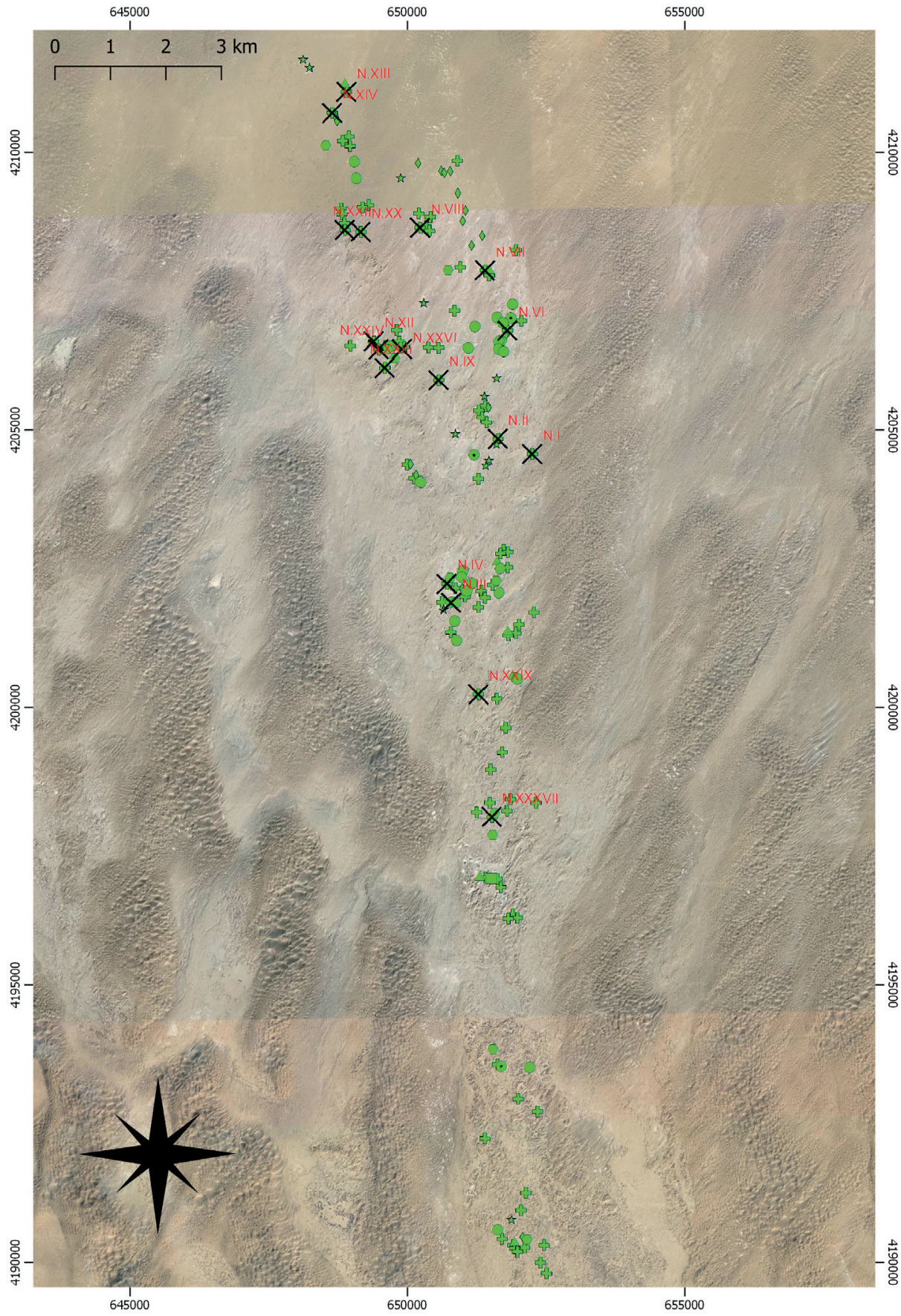

Fig. 15. Distribution of the residential buildings at the site of 尼雅 / Niya. Each structure is represented by a dot, and the contemporary satellite image is in the background. The coordinate system of the grid is UTM zone 44. (Image by the author and Joanna Koczur. Source of data: SJJRNS 1999 and Google Earth) 


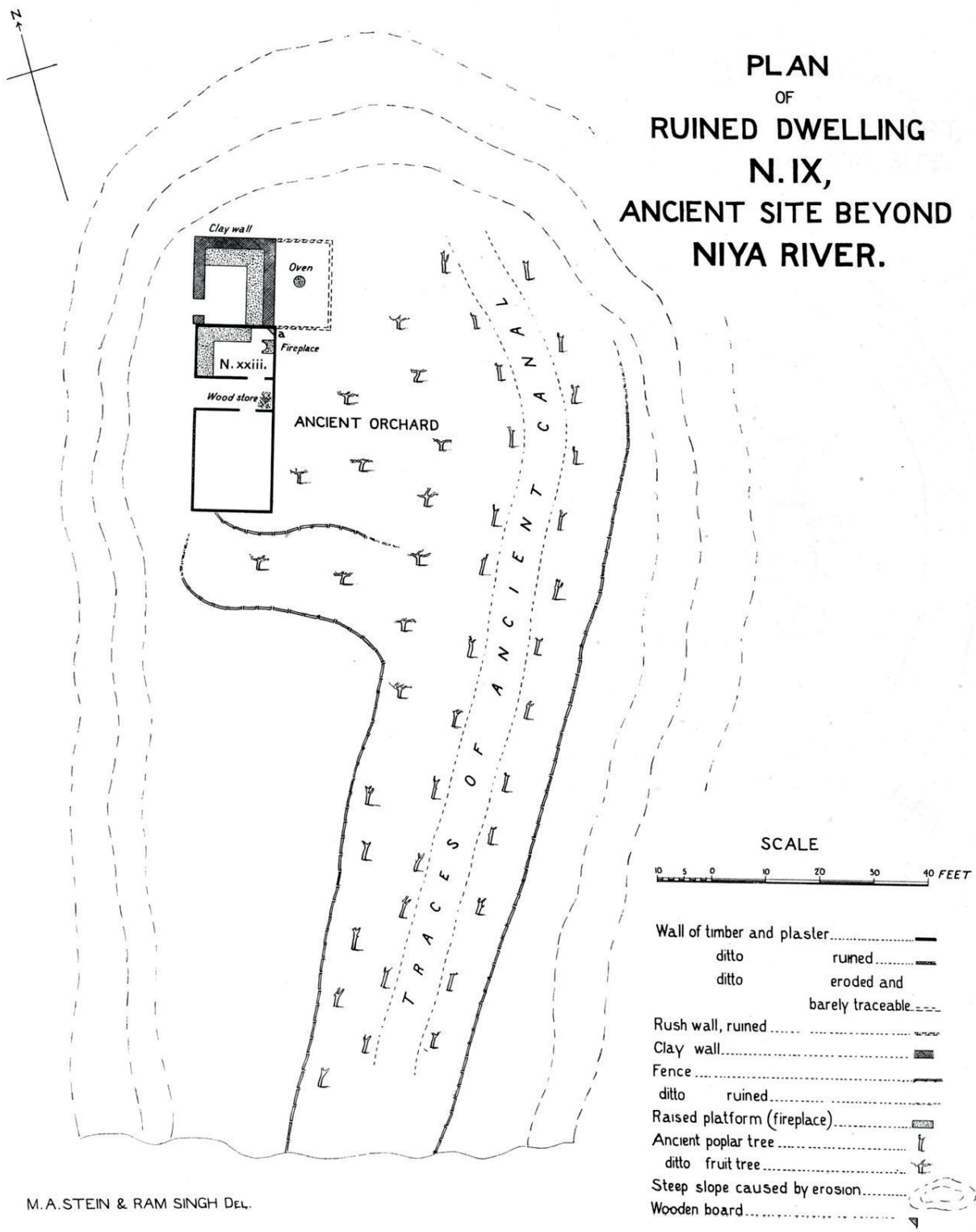

Fig. 16. The private residence N.IX from the site of 尼雅 / Niya with neighbouring food production area - an orchard and the canal. (Image source: Stein 1907) 


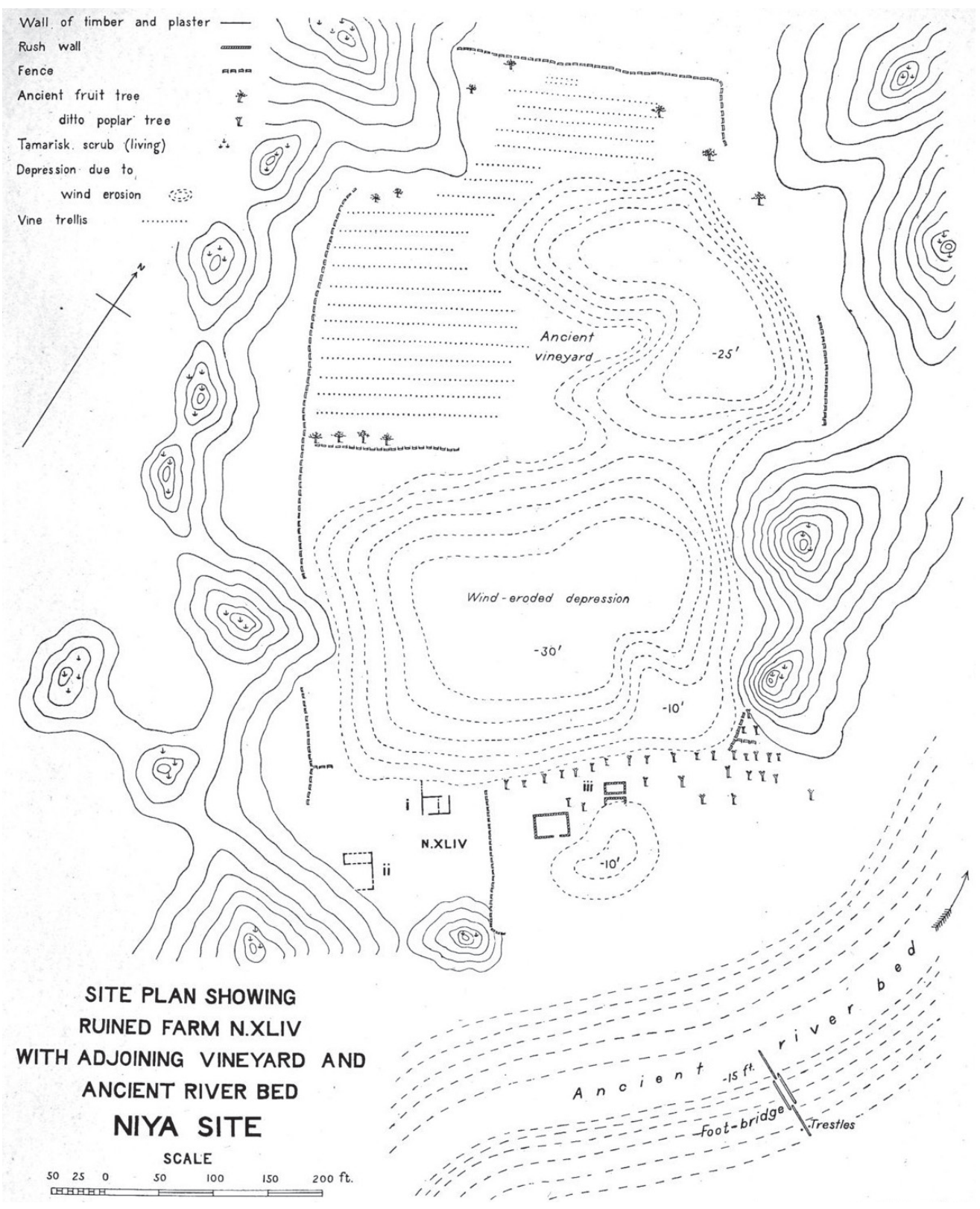

Fig. 17. A plan of compound N.XLIV and a surrounding landscape, based on Stein's field observations. (Image source: Stein 1928) 


\section{DISCUSSION}

Despite some disparities in the state of preservation of specific categories of relicts, the archaeological data for each of the oases shows a coherent model of the settlement pattern in the southern Tarim Basin. The human habitation formed a polynucleated network centred around administrative residences of high-ranking executive, fiscal, and juridical officials. Those compounds were places of social interactions, which, as discussed in sections 1. and 2., are associated with the urban functions defined by Marcus (1983) and other "functionalists" (e.g., Smith, 2016). Those interactions included public meetings in monumental halls and circulation of documents, among other activities which most likely took place but are invisible in the archaeological record. Most of the oasis dwellers inhabited households, most of which have been erased from the archaeological record due to the harsh conditions of the Taklamakan desert (Stein, 1907, 1921, 1928).

Nevertheless, more than fifty of such structures has been documented at the site of 尼雅 [Niya] which permits some general observations that in the opinion of the author can be extrapolated to the remaining two case studies. First of all, the habitation seems to be evenly distributed in the landscape, with a limited degree of concentration around administrative residences. Secondly, the clusters of houses usually consisted of a single farm or few households and outbuildings (except site N.II, where c. fifteen or sixteen structures, including both administrative and more modest commoners' dwellings has been aggregated) which were separated by cultivated areas and irrigation infrastructure. The full extent of the scope, to which large scale water projects have transformed the landscape, is possible to assess only at the site of 米兰 [Miran]. The whole area associated with that ancient oasis is covered with canals which are interpreted as part of a continuous water management system. Therefore, the statement that the whole landscape was engineered to facilitate food production is justified. The indirect evidence, which is isolated sections of canals and historical texts discussing irrigation, provides substantial premises to assume that the massive water infrastructure was present at two other sites discussed in this article.

The urban landscape of the Tarim Basin oases varied from urban forms known from Europe, the Mediterranean Basin, China or South-West Asia. In contrast to 尼 雅 [Niya], 米兰 [Miran] or 樓蘭 [Loulan], the settlements conventionally called as compact cities presented a dichotomy between densely populated spaces and their hinterland, which included differing sets of human activities in intra- and extramural areas, and extended chain of the food supply. This outcome stresses a global diversity of settlement patterns which should not be studied using the Eurocentric frame of reference exclusively. 


\section{CONCLUSIONS}

The author reached similar conclusions to Moore (2017), who attempted to assess Celtic oppida as low-density urban complexes. Given so many quantitative and qualitative variables related to past urban settlements across time and space, it is impossible to create any universal typology. Therefore an attempt to, for example, prove or disprove that Angkor shared the same urban characteristics as 米兰 [Miran], 尼雅 [Niya] and 樓蘭 [Loulan] is pointless, as it provides no meaningful information. On the other hand, the author sees excellent potential in the agro-urban landscape model to deconceptualise Eurocentric bias while interpreting archaeological data.

The revised definition proposed by Graham and Isendahl $(2018,176)$ emphases that "a substantive amount of urban/city space is dedicated to food growing" constitutes an agro-urban landscape. In the light of data from the sites of 米兰 [Miran], 尼雅 [Niya] and 樓蘭 [Loulan], the argument can be made that oases of southern Tarim Basin were such landscapes. The direct and proxy evidence suggests the past existence of the polynucleated landscape where all features associated with low-density urbanism were presented: a core of monumental architecture, massive infrastructural projects and dispersed pattern of occupation. The landscape of the oases was engineered by the creation of continuous irrigation networks, which transformed arid land into agricultural fields. As a result, agricultural land dominated the cityscape. Furthermore, both the monumental and residential architecture was dispersed within this agrarian landscape - therefore, the dichotomy between the compact urban core and its hinterland was not observed.

It does not mean that an equal sign can be put between urban forms of the Tarim Basin, the Maya lowlands or continental South-East Asia. However, applying the results of studies on two latter regions allowed the author to notice Tarim's settlement pattern elements which most likely would be overlooked if categories used to describe European cities would be applied.

\section{Acknowledgements}

The research, which results this paper communicates, is an integral part of the "The water, the sand and the folk: understanding the role of water in the social life of the oasis-cities of Shan Shan Kingdom" project funded by the Polish National Science Centre under Etiuda 6 programme (grant no. 2018/28/T/HS3/00159).

Digital Globe Foundation provided detailed satellite images under free satellite imagery grant scheme.

The author is grateful to R. Christie Research Charitable Trust for funding a research visit in London and professor Yang Lin with the staff of the National Museum of China for their hospitality during a field trip to Xinjiang. 
The author also appreciates the help of Prof. Włodzimierz Rączkowski, Dr Tim Williams, Dr. Dawid Kobiałka and Dr. Mariusz Drzewiecki, who commented draft of the manuscript, and Dr. Damien Huffer and Ms. Katarzyna Hanus, Ms. Sonia Tomczak for proof-reading, yet all errors are author's own. Ms. Joanna Koczur helped the author with illustrations 4, 10, 12 and 15.

Finally, the author would like to thank anonymous reviewers for their feedback.

\section{REFERENCES}

Atwood, C.

1991 Life in Third-fourth Century Cadh'ota: A survey of information gathered from the Prakrit documents found north of Minfeng (Niyä). Central Asiatic Journal, 35(3/4), 161-199.

Bertrand, A.

2012 Water Management in Jingjue 精絕 Kingdom: The Transfer of a Water Tank System from Gandhara to Southern Xinjiang in the Third and Fourth Centuries C. E. Sino-Platonic Papers, 223, 1-84.

Canuto, M. A., Estrada-Belli, F., Garrison, T. G., Houston, S. D., Acuña, M. J., Kováč, M., Chatelain, D. 2018 Ancient lowland Maya complexity as revealed by airborne laser scanning of northern Guatemala. Science, 361(6409), eaau0137.

Chen, G.

1984 Xinjiang Milan gucheng guangai qudao jiqi xiangguan de yixie wenti (The ancient irrigation canals of the Milan City in Xinjiang and some related questions). Kaogu Yu Wenwu, 6, 91-102.

Childe, V. G.

1950 The Urban Revolution. Town Planning Review, 21, 3-17.

Cleary, M. N.

2013 Khorezmian Walled Sites of the Seventh Century Bc - Fourth Century Ad: Urban Settlements? Elite Strongholds? Mobile Centres? Iran, 51(1), 71-100.

Cowgill, G. L.

2004 Origins and development of urbanism: archaeological perspectives. Annual Review of Anthropology, 33, 525-549.

Debaine-Francfort, C., Idriss, A., Binghua, W.

1994 Agriculture irriguée et art bouddhique ancien au cœur du Taklamakan (Karadong, Xinjiang, II e-IV e siècles). Arts asiatiques, 34-52.

Di Cosmo, N.

2000 Ancient city-states of the Tarim Basin. In M. H. Hansen (ed.), A Comparative Study of Thirty City-State Cultures (p. 393-407). Copenhagen: The Royal Danish Academy of Sciences and Letters.

Evans, D.

2016 Airborne laser scanning as a method for exploring long-term socio-ecological dynamics in Cambodia. Journal of Archaeological Science, 74, 164-175.

Evans, D., Pottier, C., Fletcher, R., Hensley, S., Tapley, I., Milne, A., Barbetti, M.

2007 A comprehensive archaeological map of the world's largest preindustrial settlement complex at Angkor, Cambodia. Proceedings of the National Academy of Sciences, 104(36), 14277-14282.

Evans, D. H., Fletcher, R. J., Pottier, C., Chevance, J. B., Soutif, D., Tan, B. S., Cromarty, C.

2013 Uncovering archaeological landscapes at Angkor using lidar. Proceedings of the National Academy of Sciences, 110(31), 12595-12600. 
Fernández-Götz, M., Krausse, D. (eds)

2016 Eurasia at the Dawn of History: Urbanisation and Social Change. Cambridge: Cambridge University Press.

Fletcher, R.

2007 The limits of settlement growth: A theoretical outline. Cambridge: Cleary, M. N.

2013 Khorezmian Walled Sites of the Seventh Century Bc - Fourth Century Ad: Urban Settlements? Elite Strongholds? Mobile Centres? Iran, 51(1), 71-100.

2009 Low-Density, Agrarian-Based Urbanism: A Comparative View. Insights, 2(4), 2-19.

2012 Low-density, agrarian-based urbanism: scale, power, and ecology. In Michael E Smith (ed.), The Comparative Archaeology of Complex Societies (p. 285-320). New York, U.S.A.: Cambridge University Press.

Fletcher, R., Penny, D., Evans, D., Pottier, C., Barbetti, M., Kummu, M., Lustig, T.

2008 The water management network of Angkor, Cambodia. Antiquity, 82, 658-670.

Fournet, T.

2001 Architecture traditionnelle et activités domestiques In C. Debaine-Francfort, A. Idriss (eds), Keriya, mémoires d'un fleuve : Archéologie et civilisation des oasis du Taklamakan (p. 34-47). Paris: Findakly.

Garrison, T. G., Houston, S., Firpi, O. A.

2019 Recentering the rural: Lidar and articulated landscapes among the Maya. Journal of Anthropological Archaeology, 53, 133-146.

Gaubatz, P. R.

1996 Beyond the Great Wall: Urban form and transformation on the Chinese frontiers. Stanford: Stanford University Press.

Graham, E., Isendahl, C.

2018 Neotropical Cities as Agro-Urban Landscapes: Revisiting'Low-Density, Agrarian-Based Urbanism'. In A. Ekblom, C. Isendahl, K.-J. Lindholm (eds), The resilience of heritage : cultivating a future of the past : essays in honour of Professor Paul J.J. Sinclair (p. 165-180). Uppsala: Uppsala University Press.

Guang-Da, Z.

1996 The city-states of the Tarim Basin. History of the Civilisations of Central Asia, 3, $282-297$. Hansen, G., Ashby, S. P., Baug I.

2008 Everyday products in the Middle Ages. Crafts, consumption and the individual in northern Europe c. AD 800-1600: an introduction. In G. Hansen, S. P. Ashby, I. Baug (eds), Everyday products in the Middle Ages. Crafts, consumption and the individual in northern Europe c. AD 800-1600 (p. 1-11). Oxford: Oxbow Books.

Hansen, V.

2012 The Silk Road: A New History. Oxford University Press.

Hanus, $\mathrm{K}$.

2020 The water, the sand and the folk: understanding the role of water in the social life of the oasis-cities of Shan Shan Kingdom. Unpublished PhD dissertation, Adam Mickiewicz University.

Hanus, K., Kostyrko M., Mardas, J.

2016 Kosmiczna pomoc. Zastosowanie danych satelitarnych w rozpoznaniu i zarządzaniu dziedzictwem archeologicznym. Maska. Magazyn Antropologiczno-Społeczno-Kulturowy, 45-60.

Hiebert, F. T.

1992 The oasis and city of Merv (Turkmenistan). Archeologie Islamique, 3, 111-127.

Isendahl, C.

2012 Agro-urban landscapes: the example of Maya lowland cities. Antiquity, 86(334), 1112-1125.

Isendahl, C., Smith, M. E.

2013 Sustainable agrarian urbanism: The low-density cities of the Mayas and Aztecs. Cities, 31, $132-143$. 
Jing. A., 景爱.

1999 沙漠考古通论. Beijing: 紫禁城出版社.

Lamberg-Karlovsky, C. C.

1994 The Bronze Age" khanates" of Central Asia. Antiquity, 68(259), 398.

Legge, J.

1991 A Record of Buddhistic Kingdoms. Mineola, NY: Dover Publications.

Li, Y., Storozum, M. J., Wang, X., G.u. Asaponarao., W.

2017 Early irrigation and agropastoralism at Mohuchahangoukou (M.G.K.), Xinjiang, China. Archaeological Research in Asia, 12, 23-32.

Luo., L., Wang, X., Liu., J., Guo., H., Lasponara, R., Ji, W., Liu, C.

2017 Uncovering the ancient canal-based tuntian agricultural landscape at China's northwestern frontiers. Journal of Cultural Heritage, 23, 79-88.

Lucero, L., Fletcher, R., Coningham, R.,

2015 From 'collapse' to urban diaspora: the transformation of low-density, dispersed agrarian urbanism. Antiquity, 89(347), 1139-1154.

M.a., Y., Wang, B.

1994 The culture of the Xinjiang region. History of civilisations of Central Asia, 2, 209-225.

Mallory, J. P.

2010 Bronze age languages of the Tarim basin. Expedition: The magazine of the University of Pennsylvania, 52, 44-53.

Marcus, J.

1983 On the nature of the Mesoamerican city. In E. Z. Vogt, R. M. Leventhal (eds), Prehistoric settlement patterns: Essays in honor of Gordon R. Willey (p. 195-242). Albuquerque: University of New Mexico Press.

Marcus, J., Sabloff, J. A.

2008 The Ancient City: New Perspectives on Urbanism in the Old and New World. Santa Fe, NM: A School for Advanced Research Resident Scholar Book.

Miksic, J. N.

2000 Heterogenetic cities in premodern Southeast Asia. World Archaeology, 32(1), 106-120.

Moore, T.

2017 Beyond Iron Age' towns': Examining oppida as examples of low-density urbanism. Oxford Journal of Archaeology, 36(3), 287-305.

Nimick, T. G.

2005 The Selection of Local Officials Through Recommendations In Fifteenth-century China. T'oung Pao, 91(1), 125-182.

Padwa, M. E.

2007 An archaic fabric: Culture and landscape in an early Inner Asian oasis (3 $\mathrm{rd}-4$ th century

C.E. Niya). Harward: Unpublished PhD dissertation, Harvard University.

Renfrew, C.

2008 The city through time and space: transformations of centrality. In J. Marcus, J. A. Sabloff (eds), The Ancient City: New Perspectives on Urbanism in the Old and New World (p. 29-52). Santa Fe, NM: A School for Advanced Research Resident Scholar Book.

Revell, L.

1999 Constructing Romanitas: Roman Public Architecture and the Archaeology of Practice. Theoretical Roman Archaeology Journal, 9, 52-58.

Rhie, M. M.

1999 Early Buddhist Art of China and Central Asia: Later Han, three kingdoms and Western

Chin in China and Bactria to Shan-shan in Central Asia, vol. 1. Leiden: Brill.

Sinclair, P., Isendahl, C., Barthel, S.

2016 Beyond rhetoric: Towards a framework for an applied historical ecology of urban planning. In C. Isendahl, D. Stump (eds) The Oxford Handbook of Historical Ecology and Applied Archaeology. Oxford - New York: Oxford University Press. 
Sino-Japanese Joint Research of the Niya Site

1999 中日共同尼雅遺跡学術調考 察隊 In 中日共同尼雅遺跡学術调查报告 书: Qrumqi/ Kyoto.

Smith, M. E.

2009 V. Gordon Childe and the Urban Revolution: a historical perspective on a revolution in urban studies. Town Planning Review, 80(1), 3-29.

2016. How can archaeologists identify early cities? Definitions, types, and attributes. In M. Fernández-Götz, D. Krausse (eds), Eurasia at the Dawn of History Urbanization and Social Change (p. 153-168). New York: Cambridge University Press.

Smith, M. L.

2003 The Social Construction of Ancient Cities. Washington D. C.: Smithsonian Institution Press.

Stein, A.

1907 Ancient Khotan: Detailed report of archaeological explorations in Chinese Turkestan. Oxford: Clarendon Press.

1921 Serindia: Detailed report of explorations in Central Asia and westernmost China. Oxford: Clarendon Press.

Trigger, B. G.

1972 Determinants of urban growth in pre-industrial societies. Warner Modular.

1990 Monumental architecture: a thermodynamic explanation of symbolic behaviour. World Archaeology, 22(2), 119-132.

2003 Understanding early civilisations: a comparative study. Cambridge University Press.

Von Falkenhausen, L.

2008 Stages in the development of "cities" in pre-Imperial China. In Marcus, J., Sabloff, J. A. (eds), The Ancient City: New Perspectives on Urbanism in the Old and New World (p. 209-228). Santa Fe, NM: School for Advanced Research.

Whitfield, S.

2004 Aurel Stein On The Silk Road. Chicago: Serindia Publications.

Willey, G. R.

1962 Mesoamerica. In R. J. Braidwood, G. R. Willey (eds), Courses toward urban life: Archaeological considerations of some cultural alternates (p. 84-105). Chicago: Aldine.

Zürcher, E.

1990 Han Buddhism and the Western Region In W. L. Idema and E. Zurcher (eds), Thought and Law. Qin and Han China: Studies Dedicated to Anthony Hulsewe on the Occasion of His Eightieth Birthday (p. 158-182). Brill.

\section{CZY MIASTA POŁUDNIOWEJ ODNOGI JEDWABNEGO SZLAKU W KOTLINIE TARIM W CHINACH BYŁY ROZPROSZONYMI ZESPOŁAMI MIEJSKIMI?}

\section{Streszczenie}

Chiński mnich 法顯 [Făxiăn], który na początku V wieku n.e. przemierzał miasta-oazy Kotliny Kaszgarskiej, zanotował, że „[...] w tej krainie domy oddalone są od siebie niczym gwiazdy na niebie" (Legge, 1991; tłumaczenie na język polski: autor). Z tego powodu liczni archeolodzy i historycy kwestionowali miejski status oaz. Niemniej ośrodki te były centrami życia gospodarczego, politycznego, religijnego i społecznego, co w Europie, na Bliskim Wschodzie oraz w Chinach uznawano za cechę „miejskiego stylu życia”. Tą potencjalną rozbieżność między fizycznymi a społeczno-funkcjonalnymi cechami miasta może rozwiązać interpretacja źródeł archeologicznych 
i historycznych przez pryzmat teorii rozproszonego urbanizmu, której zostaną poddane trzy wybrane stanowiska archeologiczne z tego regionu: 尼雅 [Niya], 米兰 [Miran] or 樓蘭 [Loulan].

Miasta starożytnego Bliskiego Wschodu, basenu Morza Śródziemnego, średniowiecznej Europy czy Chin uznaje się za centra osadnicze o całkowitej populacji oraz gęstości zaludnienia przewyższającej inne jednostki osadnicze w regionie. Miasto było często oddzielone od otaczającego go krajobrazu przez fizyczne (np. mury miejskie) i społeczne (np. rzymskie pomerium) bariery. Niemniej, co najmniej od lat 60 . XX w. archeolodzy zauważyli, że liczne cywilizacje pozaeuropejskie w swojej strukturze osadniczej nie posiadają odpowiedników klasycznego czy średniowiecznego miasta. Rozwiązaniem tego paradoksu miała być propozycja nowej definicji miasta, która nie opierała się na cechach demograficznych, ale na funkcji socjoekonomicznej. Na bazie tych rozważań na przełomie XX i XXI w. badacze, tacy jak R. Fletcher (2007, 2009, 2012), wprowadzili pojęcie rozproszonego urbanizmu.

Mimo że model rozproszonego miasta nie zakłada sztywnych ram i definicji, wyróżnić można trzy cechy wspólne, których analiza może ukierunkować analizę źródeł archeologicznych i historycznych. Pierwszą z wymienionych cech jest obecność klastrów architektury monumentalnej, definiowanej jako budynki, których skala i poziom wyrafinowania przekracza użytkowe cechy, dla których zostały zaprojektowane. Monumentalne budynki, takie jak między innymi świątynie i pałace, były centrum życia społecznego i politycznego, które często wiąże się z tzw. „miejskim stylem życia”. Drugą z charakterystyk miasta rozproszonego jest występowanie wielkoskalowych antropogenicznych modyfikacji terenu, na przykład kanałów irygacyjnych, sieci zbiorników retencyjnych czy pól tarasowych. Trzecią cechą jest rozproszona zabudowa, tworząca homogeniczny krajobraz położonych naprzemiennie poszczególnych domostw lub małych ich skupisk oraz pól uprawnych.

Celem badań, których wynik został przedstawiony w niniejszym artykule, było lepsze zrozumienie struktury osadniczej oaz w Kotlinie Kaszgarskiej, analizując dane archeologiczne i historyczne przez pryzmat opisanych powyżej cech. Oazy będące studiami przypadku, 尼雅 [Niya], 米 兰 [Miran] or 樓蘭 [Loulan], zlokalizowane są w południowo-wschodniej części Kotliny, u stóp łańcucha górskiego Ałtyn-Tag. Z powodu oddalenia od oceanów i cienia opadowego, rzeki czerpiące z wysokogórskich lodowców były i są głównym źródłem wody dla lokalnych społeczności. W czasach prahistorycznych obszar Kotliny zamieszkany był przez społeczności pasterskie, z których przynajmniej część w okresie poprzedzającym powstanie pierwszych złożonych protopaństw posługiwała się językami indoeuropejskimi (z grupy tocharskiej lub wschodnioirańskiej). Od II w. p.n.e. istnienie lokalnych „królestw” poświadczone jest przez źródła chińskie. W I w. p.n.e. lokalne państewka, w tym obejmujące omawiane oazy Królestwo Krorainy, zostały zwasalizowane przez Cesarstwo Chińskie. Powołany Protektorat Regionów Zachodnich służył kontroli polityki zagranicznej i militarnej lokalnych państw, niemniej ich władcy mieli znaczną swobodę w zakresie kształtowania polityki wewnętrznej. Na początku III w. n.e. następiły zmiany kulturowe, związane z szerokim zaadaptowaniem religii buddyjskiej i pewnych elementów kultury z Subkontynentu Indyjskiego, na przykład pismo Kharoșṭhī, które ukształtowało się terenie współczesnego Pakistanu. Po IV w. n.e. nastąpiło stopniowe wyludnianie się oaz, które najczęściej interpretuje się zmianami klimatycznymi i związanymi z nimi niedoborami wody.

Pierwsza z badanych oaz to 樓蘭 [Loulan] położona na brzegach obecnie wyschniętego jeziora Łob-nor. Obszar 樓蘭 [Loulan] badany był w pierwszej połowie XX w. przez węgiersko-brytyjskiego archeologa Aurela Steina, który zadokumentował kilkanaście kompleksów ruin oznaczonych L.A.-L.M. Kompleksy te zgrupowane są w trzech skupiskach: północnym, środkowym i południowym. Struktura przestrzenna każdego ze zgrupowań jest podobna. W centrum każdego z kompleksu znajdują się ruiny założenia otoczonego murami, niemniej obszar ufortyfikowanej przestrzeni jest zbyt mały, aby nazwać to założenie miastem. Dla przykładu ufortyfikowana przestrzeń oznaczona jako L.E., będąca centrum północnego kompleksu ruin, ma wymiary jedynie około 190 
na $100 \mathrm{~m}$. W mojej interpretacji ruiny te były ufortyfikowaną rezydencją lokalnych władców lub wysokich rangą funkcjonariuszy aparatu władzy. Za interpelacją tą przemawiają źródła archeologiczne oraz etnohistoryczne obserwacje XIX-wiecznych społeczeństw Azji Środkowej. Wewnątrz murów obronnych znajdowały się monumentalne świątynie i sale spotkań, pokoje skrybów, magazyny oraz część mieszkalna. W promieniu kilku kilometrów od każdej z tych ufortyfikowanych rezydencji archeolodzy odnaleźli ślady bardziej i mniej zamożnych domostw, obiektów sakralnych, cmentarzy, pól uprawnych oraz kanałów irygacyjnych.

W drugiej z omawianych oaz, 米兰 [Miran], odnaleziono sieć irygacyjną w bezprecedensowo dobrym stanie zachowania. Obszar powyżej $20 \mathrm{~km}^{2}$ został zmodyfikowany na potrzeby stworzenia spójnej sieci irygacyjnej, składającej się z ujęcia wody z pobliskiej rzeki, kanałów oraz śluz do zarządzania przepływem wody. Kanały wykonane zostały poprzez wkop w ziemi albo usypanie dwóch równoległych wałów tak, aby zachować odpowiedni kąt nachylenia. Na stanowisku zidentyfikowano również liczne (ponad 10) monumentalne budowle religijne, głównie świątynie buddyjskie oraz pozostałości jednego klasztoru. Obiekty te nie tworzyły żadnego centralnego skupiska, lecz były równomiernie rozproszone po terenie całej oazy. Niemniej pozostałości świeckiej architektury monumentalnej lub mieszkalnej nie zostały odnalezione do dzisiaj.

Trzecią badana oazą jest 尼雅 [Niya], na której terenie odnaleziono pozostałości po licznych monumentalnych założeniach administracyjnych oraz skromniejszych domach mieszkalnych. Założenia te różnią się od ufortyfikowanych rezydencji z 樓蘭 [Loulan]. Nie były one ufortyfikowane, lecz rozproszone równomiernie na terenie całej oazy. Niemniej analiza znalezionych w nich zabytków oraz rozplanowania przestrzennego wykazała, że obiekty te były centrum życia politycznego lokalnych społeczności. W centrum każdego założenia była monumentalna sala audiencyjna, do której dostęp był kontrolowany przez jeden bądź dwa przedsionki. W osobnej części kompleksu znajdowały się pomieszczenia, w których pracowali skrybowie oraz przechowywane były urzędowe dokumenty. W wydzielonej części mieszkali wysocy rangą urzędnicy oraz ich rodziny. Ze względu na słaby stan zachowania, niewiele można powiedzieć o domostwach gorzej sytuowanych warstw społecznych, kanałach irygacyjnych czy polach uprawnych. Niemniej pozostałości tych obiektów zostały znalezione na terenie całej oazy, co pozwala domniemywać, że mogły dominować w krajobrazie w okresie zamieszkania oazy.

Przedstawiona w artykule analiza źródeł, nastawiona na cechy urbanizmu rozproszonego, pozwoliła dostrzec niezauważone wcześniej cechy oaz. W odniesieniu do pierwszej cechy, w każdej z oaz występowały obszary równomiernie rozproszonej architektury monumentalnej, zarówno świeckiej, jak i sakralnej. W przypadku drugiej cechy doskonale zachowana sieć irygacyjna na stanowisku 米兰 [Miran] poświadcza skalę przekształceń terenu związanej z aktywnością człowieka. Mimo że na dwóch pozostałych stanowiskach ciągła sieć wodna nie zachowała się, odkryte sekcje kanałów pozwalają domniemywać, że analogiczny system gospodarki wodnej był używany. W przypadku trzeciej cechy rozproszenie zabudowy mieszkalnej pokazuje, że w oazach nie istniały obszary zwartej zabudowy mieszkalnej (na kształt europejskich miast czy wsi), lecz ciągły krajobraz naprzemiennych domostw i pól uprawnych.

Odejście od europocentrycznej definicji miasta pozwoliło na spojrzenie na sieć osadniczą i życie społeczno-ekonomiczne Kotliny Kaszgarskiej w zupełnie nowym świetle. Pokazuje to, jak ważne jest, aby badacze byli świadomi własnych wzorców kulturowych, a także byli ich świadomi w czasie interpretacji źródeł archeologicznych i historycznych. 